\title{
Comparing model and measured ice crystal concentrations in orographic clouds during the INUPIAQ campaign
}

\author{
Robert J. Farrington ${ }^{1}$, Paul J. Connolly ${ }^{1}$, Gary Lloyd ${ }^{1}$, Keith N. Bower ${ }^{1}$, Michael J. Flynn ${ }^{1}$, Martin W. Gallagher ${ }^{1}$, \\ Paul R. Field ${ }^{2}$, Chris Dearden ${ }^{1}$, and Thomas W. Choularton ${ }^{1}$ \\ ${ }^{1}$ School of Earth, Atmospheric and Environmental Sciences, The University of Manchester, Manchester, UK \\ ${ }^{2}$ Met Office, Exeter, UK \\ Correspondence to: Robert J. Farrington (robert.farrington@manchester.ac.uk) \\ and Paul J. Connolly (p.connolly@manchester.ac.uk)
}

Received: 17 July 2015 - Published in Atmos. Chem. Phys. Discuss.: 21 September 2015

Revised: 19 March 2016 - Accepted: 27 March 2016 - Published: 21 April 2016

\begin{abstract}
This paper assesses the reasons for high ice number concentrations observed in orographic clouds by comparing in situ measurements from the Ice NUcleation Process Investigation And Quantification field campaign (INUPIAQ) at Jungfraujoch, Switzerland (3570 m a.s.l.) with the Weather Research and Forecasting model (WRF) simulations over real terrain surrounding Jungfraujoch. During the 2014 winter field campaign, between 20 January and 28 February, the model simulations regularly underpredicted the observed ice number concentration by $10^{3} \mathrm{~L}^{-1}$. Previous literature has proposed several processes for the high ice number concentrations in orographic clouds, including an increased ice nucleating particle (INP) concentration, secondary ice multiplication and the advection of surface ice crystals into orographic clouds. We find that increasing INP concentrations in the model prevents the simulation of the mixed-phase clouds that were witnessed during the INUPIAQ campaign at Jungfraujoch. Additionally, the inclusion of secondary ice production upwind of Jungfraujoch into the WRF simulations cannot consistently produce enough ice splinters to match the observed concentrations. A flux of surface hoar crystals was included in the WRF model, which simulated ice concentrations comparable to the measured ice number concentrations, without depleting the liquid water content (LWC) simulated in the model. Our simulations therefore suggest that high ice concentrations observed in mixed-phase clouds at Jungfraujoch are caused by a flux of surface hoar crystals into the orographic clouds.
\end{abstract}

\section{Introduction}

Orographic clouds, and the precipitation they produce, play a key role in the relationship between the atmosphere and the land surface (Roe, 2005). The formation and development of each orographic cloud event varies considerably. Variations in large-scale flow over the orography, the size and shape of the orography, convection, turbulence and cloud microphysics all influence the lifetime and extent of orographic clouds, as well as the intensity of precipitation they produce (Rotunno and Houze, 2007). Understanding these variations in orographic clouds is important, as the intensity and extent of a wide-range of geophysical hazards are heavily influenced by precipitation (Conway and Raymond, 1993; Galewsky and Sobel, 2005).

The influence of aerosols on the cloud microphysical processes is thought to be important in understanding the variability of orographic clouds and precipitation. Aerosols interact with clouds by acting as cloud condensation nuclei $(\mathrm{CCN})$, onto which water vapour condenses, or as ice nucleating particles (INPs). The differing efficiencies, compositions and concentrations of both CCN and INPs in the atmosphere influence the lifetime and precipitation efficiency of clouds (Twomey, 1974; Albrecht, 1989; Lohmann and Feichter, 2005).

In particular, the role of aerosols in the production of ice in the atmosphere is poorly understood. Ice can nucleate in the atmosphere without the presence of INPs at temperatures below $-38^{\circ} \mathrm{C}$ via homogeneous nucleation (Koop et al., 2000). However, it is thought that for temperatures greater than 
$-38^{\circ} \mathrm{C}$ most ice nucleation in orographic clouds takes place heterogeneously on INPs via different freezing mechanisms: deposition, condensation freezing, immersion freezing and contact freezing (Vali, 1985). Above $-38^{\circ} \mathrm{C}$, the presence of supercooled liquid water has consistently been found to be a requirement of significant heterogeneous nucleation (Westbrook and Illingworth, 2011; de Boer et al., 2011; Westbrook and Illingworth, 2013), causing the immersion, contact and condensation freezing modes to dominate ice production at these temperatures (de Boer et al., 2011; Field et al., 2012).

Despite much uncertainty existing over the concentrations and distributions of INPs in the atmosphere (Boucher et al., 2013), particular aerosol particle types have been proposed to nucleate ice. Several studies suggest that mineral dust nucleates ice in the atmosphere (e.g. DeMott et al., 2003; Cziczo et al., 2013), although the temperature threshold below which dust aerosols nucleates ice varies significantly between studies, with some suggesting dust could act as INPs at temperatures as high as $-5^{\circ} \mathrm{C}$ (Sassen et al., 2003), whilst others found dust INPs to be inactive above $-20^{\circ} \mathrm{C}$ (Ansmann et al., 2008). Laboratory measurements of ice nucleation on desert dust aerosols have linked the varying nucleation threshold temperatures to the mineral composition of the dust particles (Connolly et al., 2009; Murray et al., 2011; Broadley et al., 2012; Niemand et al., 2012; Atkinson et al., 2013; Emersic et al., 2015). Generally the literature has suggested that mineral dust is unlikely to act as an INP at temperatures as high as $-5^{\circ} \mathrm{C}$, which has led to ongoing research into whether other aerosol components can nucleate ice at higher temperatures than mineral dust. Biological aerosols such as bacteria or pollen have been suggested as potentially being suitable to nucleate ice heterogeneously (Möhler et al., 2007), which has been supported by in situ observations (Prenni et al., 2009; Pratt et al., 2009). However, despite some laboratory experiments suggesting that certain bacteria nucleate ice at temperatures greater than $-10{ }^{\circ} \mathrm{C}$ in the atmosphere (Hoose and Möhler, 2012), there remains an uncertainty regarding the role of biological aerosols in ice nucleation at higher temperatures.

INP concentrations alone are not enough to explain ice number concentrations witnessed in some clouds. Ice concentrations in the atmosphere can also be increased by ice multiplication processes. The Hallett-Mossop process (Hallett and Mossop, 1974; Mossop and Hallett, 1974), which produces ice splinters during the riming of ice particles, has been suggested to be a dominant ice multiplication process between -3 and $-8^{\circ} \mathrm{C}$. Mossop and Hallett (1974) indicated that one splinter is produced for every 160 droplets accreted to the ice crystal, providing the droplets are greater than $20 \mu \mathrm{m}$ in diameter, and suggested that several rimesplinter cycles could increase ice number concentrations by as much as five orders of magnitude. Several examples of the Hallett-Mossop process have been presented in the literature explaining differing INP and ice number concentrations (Harris-Hobbs and Cooper, 1987; Hogan et al., 2002;
Huang et al., 2008; Crosier et al., 2011; Lloyd et al., 2014). However, the process is limited to specific regions, which are within the required temperature range, have large concentrations of supercooled liquid droplets, and in clouds with long lifetimes (> $25 \mathrm{~min}$ ) and weak updraughts (Mason, 1996). More recently Lawson et al. (2015) have shown fragmentation of freezing drops can also act as a secondary ice multiplication mechanism in the absence of the Hallett-Mossop process, particularly in cumuli with active warm rain processes.

Despite considerable improvement in the understanding of ice production processes in the atmosphere, much confusion remains in understanding the sources of ice measured in orographic clouds. Several studies have found significantly high ice number concentrations at mountain sites when compared to aircraft observations. Rogers and Vali (1987) frequently found ice concentrations close to the surface of Elk Mountain to be three orders of magnitude higher than ice concentrations measured by aircraft $1 \mathrm{~km}$ above the mountain. The increased concentrations could not be explained by the Hallett-Mossop ice multiplication, leading them to suggest the possibility of surface ice or snow crystals being blown into the cloud. Vali et al. (2012) proposed that ground-layer snow clouds, formed by snow or ice particles being blown from the surface into air supersaturated with respect to ice, were responsible for the increased ice number concentrations. Targino et al. (2009) found two cases of high ice concentrations at Jungfraujoch in Switzerland, and suggested that the high ice concentrations were unlikely to be caused by mineral-dust INPs, as no significant increase in dust concentrations was observed. They suggested that polluted aerosol, such as black carbon, acted as INPs and increased the ice concentration close to the surface. During the Ice NUcleation Process Investigation And Quantification field campaign (INUPIAQ) undertaken during the winter of 2013 and 2014, Lloyd et al. (2015) found ice number concentrations of over $\sim 2000 \mathrm{~L}^{-1}$ at $-15^{\circ} \mathrm{C}$. By using measured aerosol concentrations in the parameterisation of DeMott et al. (2010), they predicted INP concentrations which were as much as 3 orders of magnitude smaller than the ice number concentration. Whilst their findings suggested that blowing snow contributed to the ice number concentrations, they found the effect could not fully explain the high ice concentration events where concentrations were $>100 \mathrm{~L}^{-1}$. However, they suggested that a flux of particles from the surface, such as surface hoar crystals, could provide enough ice crystals to match the high ice number concentrations witnessed in their field campaign.

With aerosol- and cloud-particle measurements limited over mountainous regions, research into orographic clouds has been driven by the modelling community. However, the complexity of the atmospheric dynamics, cloud microphysics and terrain has often led to a restricted approach in investigating orographic clouds (Kunz and Kottmeier, 2006; Barstad et al., 2007; Cannon et al., 2014). Whilst 3-D at- 
mospheric models provide a more accurate representation of the complex airflow, which mountainous terrain generates, the computational expense has generally limited studies of aerosol-cloud interactions in orographic clouds to 2-D simulations (Lynn et al., 2007; Zubler et al., 2011) or idealised terrain (Xiao et al., 2014). Recently, Muhlbauer and Lohmann (2009) performed 3-D simulations over idealised orography to investigate the influence of aerosol perturbations of dust and black carbon on the cloud microphysical processes in mixed-phase clouds. The simulations were run using a twomoment mesoscale model with coupled aerosol and cloud microphysics and 3-D idealised orography. Muhlbauer and Lohmann (2009) suggested that aerosols are critical in initiating ice in mixed-phase orographic clouds. However the strength of their conclusions are limited to the idealised terrain used in the model and for the specific aerosol data from 2009.

By drawing on previous research into orographic clouds using modelling, this paper aims to assess the reasons for high ice number concentrations at mountain sites by comparing the in situ measurements of Lloyd et al. (2015) from the INUPIAQ campaign with simulations over real terrain from the Weather Research and Forecasting model (WRF). In Sect. 2, we outline the characteristics of the field site and the instrumentation used to measure cloud microphysical properties, before providing a description of the implementation of the WRF model. In Sect. 2.4, we provide validation of the model using meteorological data from stations throughout the model domain. The in situ ice number concentrations are then compared with the WRF model in Sect. 3, before analysing the processes proposed in previous literature for increasing ice concentrations in orographic clouds using further WRF simulations. Finally, in Sect. 4, we evaluate the suggested processes that cause high ice concentrations in orographic clouds, and draw conclusions from our results.

\section{Methodology}

\subsection{Jungfraujoch}

Cloud-particle number concentrations and size distributions were measured at the Jungfraujoch high-alpine research station, located in the Bernese Alps in Switzerland. Jungfraujoch is an ideal location to measure microphysical properties of clouds, as the altitude of the site $(3570 \mathrm{ma.s.1}$.) allows measurements to be within cloud $37 \%$ of the time (Baltensperger et al., 1998). The site is only accessible by electric train, which limits the influence of local anthropogenic emissions on measurements taken at Jungfraujoch (Baltensperger et al., 1997). The site has regularly been used for cloud and aerosol research by groups from the Paul Scherrer Institute, Karlsruhe Institute of Technology, University of Manchester and other institutions (e.g. Baltensperger et al., 1997, 1998;
Verheggen et al., 2007; Choularton et al., 2008; Targino et al., 2009; Lloyd et al., 2015).

\subsection{Instrumentation at Jungfraujoch}

Several cloud physics probes using a variety of measurement techniques were used for measuring cloud-particle number concentrations and size distributions during the campaign. The probes were mounted on the roof terrace of the Sphinx laboratory on a rotating wing attached to a $\sim 3 \mathrm{~m}$ high tall mast, which was automatically rotated and tilted to face into the wind based on the measured wind direction to minimise inlet sampling issues.

Ice concentrations were primarily measured using an aspirated Three-View Cloud Particle Imager (3V-CPI) by Stratton Park Engineering Inc (SPEC). This probe is a combination of two previously separately packaged instruments: the Two-Dimensional Stereo Hydrometeor Spectrometer (2D$\mathrm{S})$ and a Cloud Particle Imager (CPI). The 2D-S produces shadow imagery of particles by illuminating them onto 128 photodiode arrays, with a pixel resolution of $10 \mu \mathrm{m}$, as they pass through the cross section of two diode laser beams (Lawson et al., 2006). The arrays allow for 2 dimensional images of particles in the cross section of both laser beams, in addition to providing number concentrations and size distributions of particles in the size range of $10-1260 \mu \mathrm{m}$. The raw data provided were then processed using the Optical Array Shadow Imaging Software (OASIS) to segregate ice and droplets based on their shape, and to remove particles that had shattered on the 2D-S from the data set (Crosier et al., 2011). Further details of the 2D-S analysis are provided by Lloyd et al. (2015). The 2D-S particles which were determined by OASIS to be ice particles were then assigned to $10 \mu \mathrm{m}$ size bins, which were used to provide an approximation of ice water content (IWC) at Jungfraujoch using the mass-diameter parameterisation of Brown and Francis (1995).

When particle images are recorded on both arrays of photodiodes on the 2D-S, the CPI probe is activated. The CPI images the particle motion using a $20 \mathrm{~ns}$ pulsed laser, casting an image of the particle onto a 1024 by 1024 array. The $\mathrm{CPI}$ has a pixel resolution of $2.3 \mu \mathrm{m}$ and thus has a size range of between 10-2000 $\mu \mathrm{m}$ (Lawson et al., 2001). CPI produces clear images of crystals and processing of the raw data enables the habit of the crystals to be estimated. However, corrections must be made to include out-of-focus particles and for particles below $50 \mu \mathrm{m}$, as the sample volume has a size dependency for small particles (see Connolly et al., 2007).

Droplet concentrations and liquid water content (LWC) were measured by the Forward Scattering Spectrometer Probe (FSSP), and the Cloud Droplet Probe (CDP) which use the forward scattering of light from a laser to count and size water droplets of diameters of between 2 and $50 \mu \mathrm{m}$ (Lance et al., 2010). Meteorological conditions were recorded with a Vaisala probe, which measured temperature and relative hu- 
Table 1. Summary of WRF simulations used in this paper.

\begin{tabular}{ll}
\hline Name & Details \\
\hline Control & Control simulation \\
IN-1 & Simulation with INP concentration increased by multiplying the Cooper equation (Cooper, 1986) by 10 \\
IN-3 & Simulation with INP concentration increased by multiplying the Cooper equation (Cooper, 1986) by $10^{3}$ \\
Surf-6 & Simulation including a flux of surface crystals adapted from Xu et al. (2013), multiplied by $10^{6} \mathrm{~m}^{-2} \mathrm{~s}^{-1}$ \\
Surf-3 & Simulation including a flux of surface crystals adapted from Xu et al. (2013), multiplied by $10^{3} \mathrm{~m}^{-2} \mathrm{~s}^{-1}$ \\
\hline
\end{tabular}

midity, and a Metek sonic anemometer, which measured the temperature, wind speed and direction. Additionally, meteorological data were available from the MeteoSwiss observation station at Jungfraujoch for comparison. Further details of the instrumentation can be found in Lloyd et al. (2015).

\subsection{Model setup}

For a comparison with the measurements made by cloud microphysics probes at Jungfraujoch, version 3.6 of the WRF model was used (Skamarock et al., 2008). A single model domain was set up surrounding Jungfraujoch, with a horizontal resolution of $1 \mathrm{~km}$, covering 149 grid points in the north-south direction and 99 grid points in the east-west direction. The higher spatial resolution was required as the real orography is more complicated than the idealised topography used by Muhlbauer and Lohmann (2009). Ninety-nine vertical levels were used, which follow the terrain as sigma levels, providing a level spacing of between 58 and $68 \mathrm{~m}$ close to the terrain surface and between 165 and $220 \mathrm{~m}$ at the model top, which was situated at $\sim 20 \mathrm{~km}$. A time step of $3 \mathrm{~s}$ was used, to satisfy the Courant-Freidrichs-Lewy (CFL) stability criterion, as the complex orography surrounding Jungfraujoch can cause CFL violations.

The orography in the model is interpolated from surface data with a spatial resolution of $2 \mathrm{~min}$, with the height of Jungfraujoch in the model being $3330 \mathrm{~m}$ a.s.l.. The resolution of 2 min was used, as the steep gradients present in the 30 s resolution orographic data cause CFL stability problems, which prevent the model simulation from running over the Jungfrau region for the duration of the field campaign. The model was run using operational analysis data from the European Centre for Medium-range Weather Forecasting to initialise the model and provide boundary conditions at the edge of the domain, which were updated every $6 \mathrm{~h}$. The model simulations were found to have a spin-up time of $40 \mathrm{~h}$ using the vertical wind field that was output from the simulation.

To model the cloud microphysics, the Morrison twomoment scheme was used, which is described in Morrison et al. $(2005,2009)$. The number of ice crystals per litre produced from deposition and condensation freezing, $N_{\mathrm{i}, \mathrm{dc}}$, is defined in the Morrison scheme using the Cooper equation (Cooper, 1986; Rasmussen et al., 2002):

$N_{\mathrm{i}, \mathrm{dc}}=0.005 \exp \left[0.304\left(T_{0}-T\right)\right]$, where $T_{0}=273.15 \mathrm{~K}$ and $T$ is the temperature in $\mathrm{K}$. The equation is based on in situ measurements of heterogeneous ice nucleation by deposition and condensation freezing. At $T=258.15 \mathrm{~K}\left(-15^{\circ} \mathrm{C}\right)$, the parameterisation predicts ice concentrations of $0.4779 \mathrm{~L}^{-1}$. Chou et al. (2011) measured INP concentrations at Jungfraujoch of approximately $10 \mathrm{~L}^{-1}$ below water saturation using a portable ice nucleation chamber at $-29^{\circ} \mathrm{C}$, whilst Conen et al. (2015) measured concentrations of $0.01 \mathrm{~L}^{-1}$ at $-10^{\circ} \mathrm{C}$. As the Cooper parameterisation predicts INP concentrations between these values, the parameterisation can be used to assess the ice concentration at Jungfraujoch. The conditions under which the parameterisation is used were adapted for the Morrison scheme from Thompson et al. (2004), and are active either when the saturation ratio with respect to ice is greater than 1.08 or when the model is saturated with respect to water and the temperature of the model is below $-8^{\circ} \mathrm{C}$. The Morrison scheme also includes parameterisations for the freezing of droplets by contact nuclei (Meyers et al., 1992) and by immersion freezing (Bigg, 1953).

The short-wave and long-wave radiation are parameterised in the model using the Goddard scheme (Chou and Suarez, 1999). No cumulus parameterisations were used, as the resolution of the model should provide sufficient detail to resolve clouds at grid-scale.

Several WRF simulations were run as part of our investigation and these are summarised in Table 1. Each simulation was run for the time period of the INUPIAQ campaign, between 20 January 2014 00:00 UTC and 28 February 2014 00:00 UTC, and completed in a single, continuous model simulation with no reinitialised simulations used in our research. The initial WRF simulation for INUPIAQ formed a control simulation to assess the validity of the model, as well as allowing a basis for comparison with simulations adjusted to include additional microphysical processes.

\subsection{Model validation}

To assess the validity of the model, the WRF control simulation was compared with observed meteorological data from a number of MeteoSwiss observation stations throughout the domain, which are detailed in Table 2 and Fig. 1. Each site provided data for wind speed, wind direction, temperature and relative humidity, which are compared with the output 
Table 2. Locations of four MeteoSwiss stations used to obtain meteorological data throughout the INUPIAQ campaign.

\begin{tabular}{lrrrr}
\hline Site & $\begin{array}{r}\text { Latitude, } \\
{ }^{\circ} \mathrm{N}\end{array}$ & $\begin{array}{r}\text { Longitude, } \\
{ }^{\circ} \mathrm{E}\end{array}$ & $\begin{array}{r}\text { Altitude, } \\
\mathrm{m}\end{array}$ & $\begin{array}{r}\text { Model Altitude, } \\
\mathrm{m}\end{array}$ \\
\hline Jungfraujoch & 46.55 & 7.99 & 3580 & 3330 \\
Eggishorn & 46.43 & 8.09 & 2893 & 2320 \\
Grimsel Hospiz & 46.57 & 8.33 & 1980 & 2186 \\
Titlis & 46.77 & 8.43 & 3040 & 2337 \\
\hline
\end{tabular}

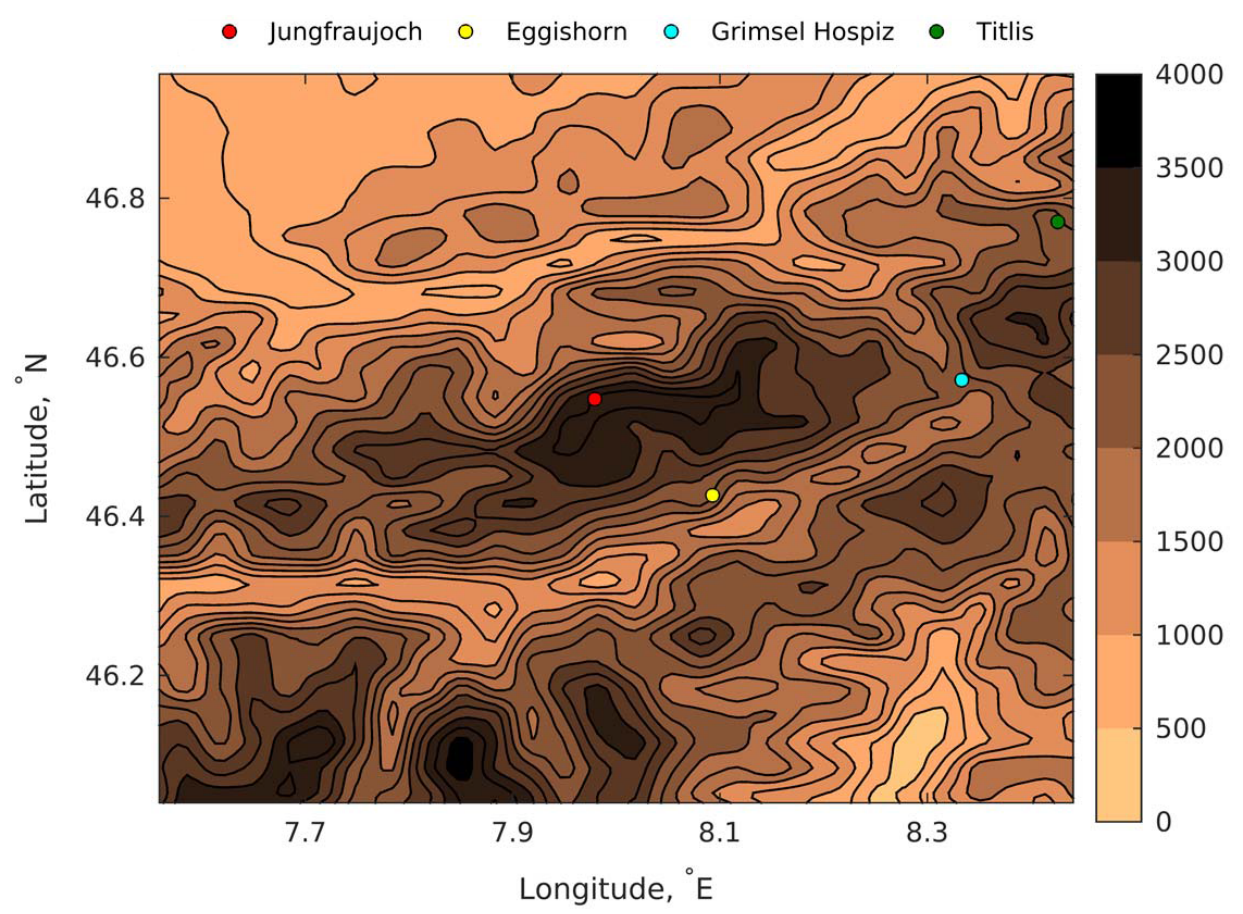

Figure 1. Location of MeteoSwiss observation stations.

from the first prognostic atmospheric level of the control simulation at each location, with the model altitudes listed in Table 2. Figures 2-5 show the comparisons for each of the meteorological variables, and the bias and root mean square error (RMSE) between the model and the observations is shown in Table 3.

Figures 2-5 show that the meteorological data compare favourably with the meteorological variables simulated in the WRF control simulation. At Jungfraujoch, the model closely follows the observed temperature throughout the campaign at all times where observed data were available, and the model and observations are in agreement, with an average bias of $0.83{ }^{\circ} \mathrm{C}$. At other sites, the simulated temperatures were less accurate, with periods during the campaign where significantly lower temperatures were observed at Titlis and lower wind speeds were observed at Grimsel Hospiz than the values determined from the WRF simulation at these sites. The RMSE between the model and observed temperature at Titlis was also higher than for the other stations. The differences between the simulation and observations at Titlis re- late to the close proximity of the station to the edge of the domain, where the model is sensitive to the boundary conditions, causing the discrepancy between the control simulation and the meteorological observations. However, as Jungfraujoch is at the centre of the model domain, the sensitivity to boundary conditions is considerably lower than at Titlis. Also, the resolution of the orography causes the height of the sites in the model to be reduced. The height at Titlis in the model is $2234 \mathrm{~m}$ a.s.1., much lower than the actual height ( $3040 \mathrm{~m}$ a.s.1.) of the site. As a result, the temperature in the model will be warmer as the location of Titlis in the model is lower in altitude. In contrast, the difference in height between the model and reality is much smaller at Jungfraujoch $(\sim 280 \mathrm{~m})$, so the difference in temperature is considerably less. Hence the MeteoSwiss data show that the model provides a good representation of the atmospheric conditions over Jungfraujoch for our research. 
(a) JFJ

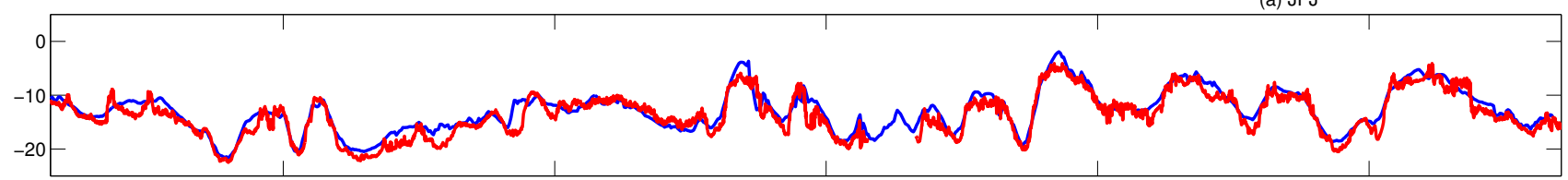

(b) Eggishorn

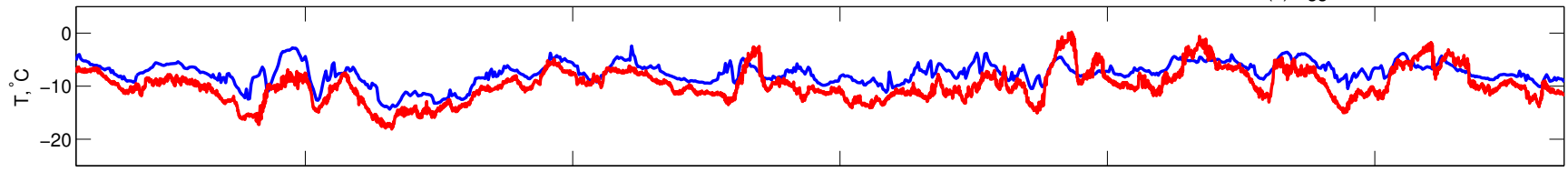

(c) Grimsel Hospiz

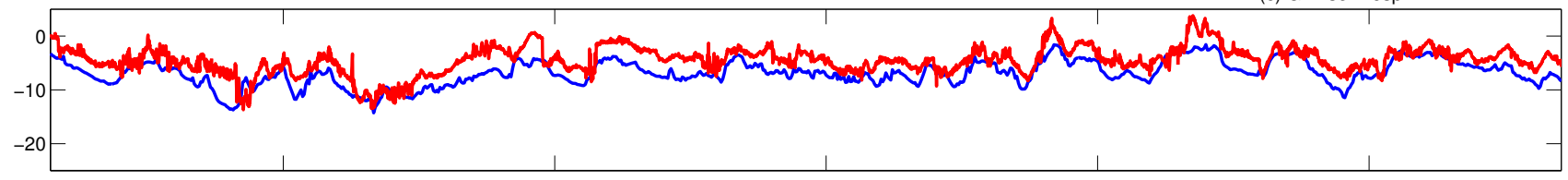

(d) Titlis

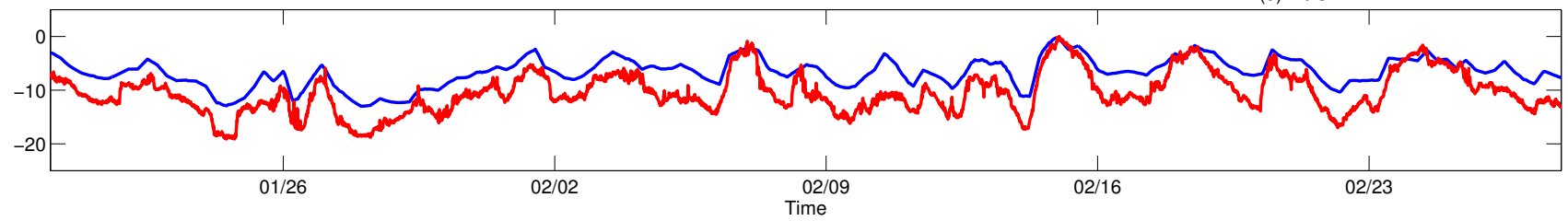

Figure 2. A comparison of the air temperature at four MeteoSwiss observation stations with the WRF control simulation during the INUPIAQ field campaign.

Table 3. Bias and root mean square error of temperature, relative humidity, wind speed and wind direction between the WRF control simulation and measurements taken at four MeteoSwiss stations.

\begin{tabular}{|c|c|c|c|c|c|c|c|c|}
\hline \multirow[b]{2}{*}{ Site } & \multicolumn{2}{|c|}{$T,{ }^{\circ} \mathrm{C}$} & \multicolumn{2}{|c|}{ Relative humidity, $\%$} & \multicolumn{2}{|c|}{ Wind speed, $\mathrm{ms}^{-1}$} & \multicolumn{2}{|c|}{ Wind direction, ${ }^{\circ}$} \\
\hline & Bias & RMSE & Bias & RMSE & Bias & RMSE & Bias & RMSE \\
\hline Jungfraujoch & 0.83 & 1.65 & 3.01 & 17.61 & -0.55 & 2.87 & -32.69 & 113.69 \\
\hline Eggishorn & 2.20 & 3.01 & 5.35 & 22.80 & 0.98 & 4.57 & -50.68 & 128.49 \\
\hline Grimsel Hospiz & -2.41 & 2.83 & 5.09 & 14.46 & 1.82 & 5.26 & 9.10 & 99.91 \\
\hline Titlis & 3.82 & 4.19 & 1.96 & 16.02 & -2.81 & 4.62 & 2.98 & 72.55 \\
\hline
\end{tabular}

\section{Comparison and explanations for differences between modelled and observed ice number concentrations}

For the duration of the campaign, the ice number concentrations recorded using the $2 \mathrm{D}-\mathrm{S}$ were compared with ice number concentrations simulated in the first atmospheric level of the WRF control simulation at Jungfraujoch (see red and blue lines in Figs. 6a and S1 in the Supplement). The control simulation regularly produced around $10^{3}$ fewer ice crystals than measured by the 2D-S at Jungfraujoch, similar to the discrepancies found in the literature between ice concentrations measured at mountain sites and on aircraft (Rogers and Vali, 1987), and between ice concentrations and predicted INP concentrations (Lloyd et al., 2015). We will now examine the cause of the discrepancy between the ice number concentrations simulated in WRF and the concentrations measured at Jungfraujoch.

\subsection{Sensitivity of simulated ice concentration to simulated INP concentration}

We first examine if the difference between modelled and measured ice concentrations is explained by additional INPs in the model. As touched upon in Sect. 2.3, measurements from previous field campaigns at Jungfraujoch have suggested varying INP concentrations of between 10 and $0.01 \mathrm{~L}^{-1}$ (Chou et al., 2011; Conen et al., 2015). Whilst the previously measured INP concentrations have varied, they are still considerably lower than the ice number concentra- 

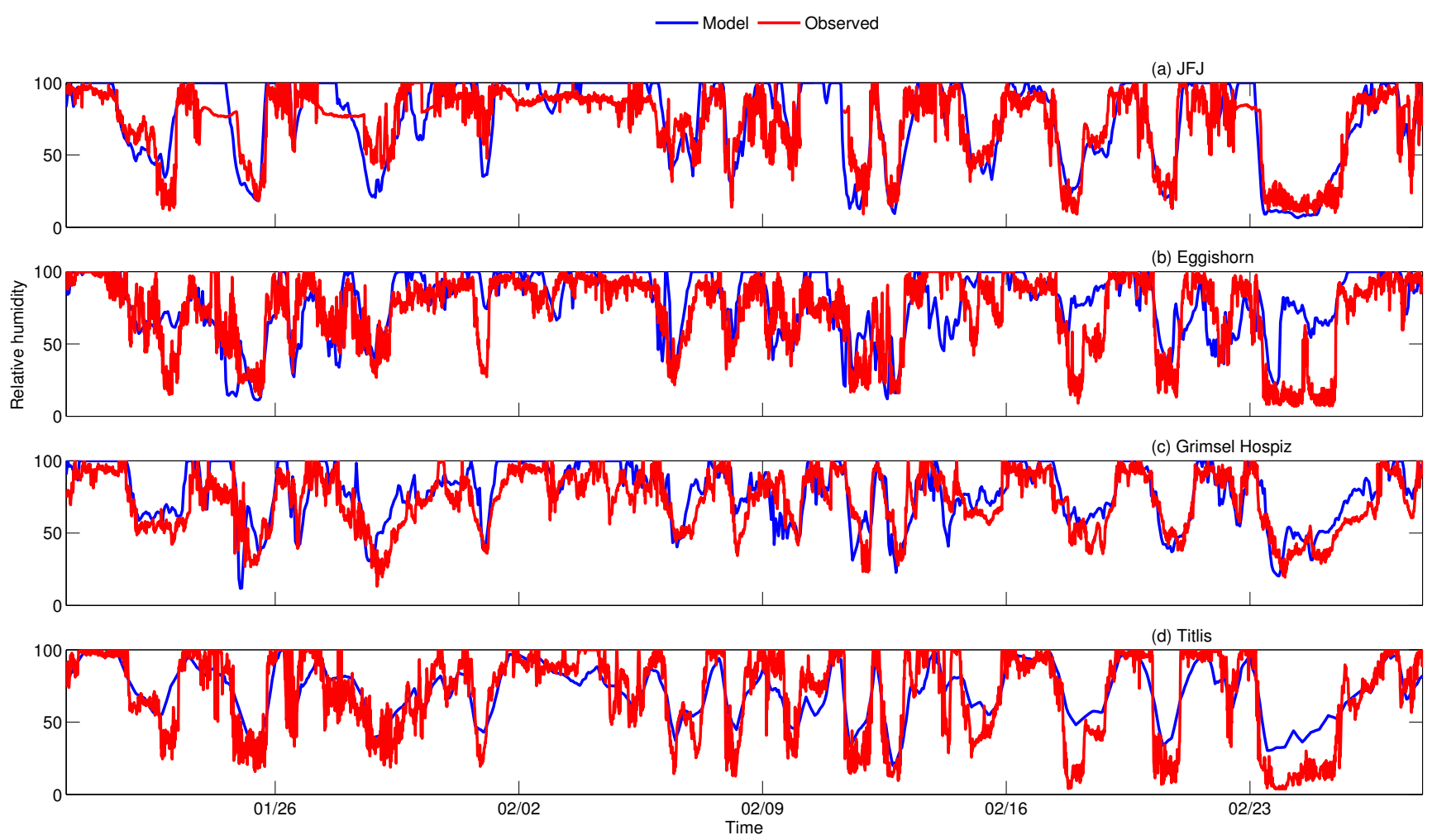

Figure 3. A comparison of the relative humidity at four MeteoSwiss observation stations with the WRF control simulation during the INUPIAQ field campaign.

tions measured at Jungfraujoch (Lloyd et al., 2015). Hence there is a possibility that other aerosols are nucleating ice which are not sampled by the instruments measuring INP concentrations at Jungfraujoch, as proposed by Targino et al. (2009).

To test this hypothesis, two further WRF simulations were run with increased INP concentrations. The INP concentrations were increased by multiplying the number of INPs per litre from the Cooper equation (Cooper, 1986) by a constant value. Whilst the number of INPs calculated by the Cooper equation is increased, we do not change the magnitude of the contact or immersion parameterisations of Meyers et al. (1992) or Bigg (1953). The INP concentrations were multiplied in the two simulations, IN-1 and IN-3, by 10 and $10^{3}$ respectively. The ice number concentrations simulated at Jungfraujoch in the control, IN-1 and IN-3 WRF simulations are compared with the 2D-S concentrations in Figs. 6a, $\mathrm{S} 1$ and $\mathrm{S} 2$ in the Supplement.

A better comparison between the model ice number concentrations and the 2D-S concentrations is found when the number of INPs is multiplied by $10^{3}$. Taken in isolation, the ice number concentration simulated in the IN-3 simulation suggests that the Cooper equation used in the Morrison scheme significantly underestimates the INP concentrations in orographic clouds and that additional INPs are present in a mountainous environment.
However, increasing the INP concentration in the Morrison scheme generally causes the LWC in the simulation to decrease (see Fig. 6b). When freezing occurs in mixed-phase clouds, ice crystals grow at the expense of liquid droplets by the Bergeron-Findeisen process. The greater INP concentration in the model increases the number of small ice crystals produced at the onset of freezing. Figure $6 \mathrm{~b}$ indicates that multiplying the INP concentration by $10^{3}$ generally causes the LWC to decrease to zero, with liquid water absent at Jungfraujoch for most of the IN-3 simulation. However, measurements from several liquid and ice cloud probes during the field campaign, as well as measurements made in previous field campaigns at Jungfraujoch, suggest liquid water is present even when large ice number concentrations are measured (Targino et al., 2009; Lloyd et al., 2015).

Additionally, Fig. $6 \mathrm{c}$ suggests that increasing the number of INPs by 3 orders of magnitude in the model fails to increase the IWC by enough to match the inferred IWC from the 2D-S. While the additional INPs have reduced the LWC to below the measured LWC at Jungfraujoch, the simulated crystals resulting from the additional INPs provide a lower IWC and hence smaller crystals than those measured by the 2D-S. Whilst increasing the INP concentration increases the IWC, this is always at expense of the LWC, suggesting that regardless of the INP concentration, the model does not con- 

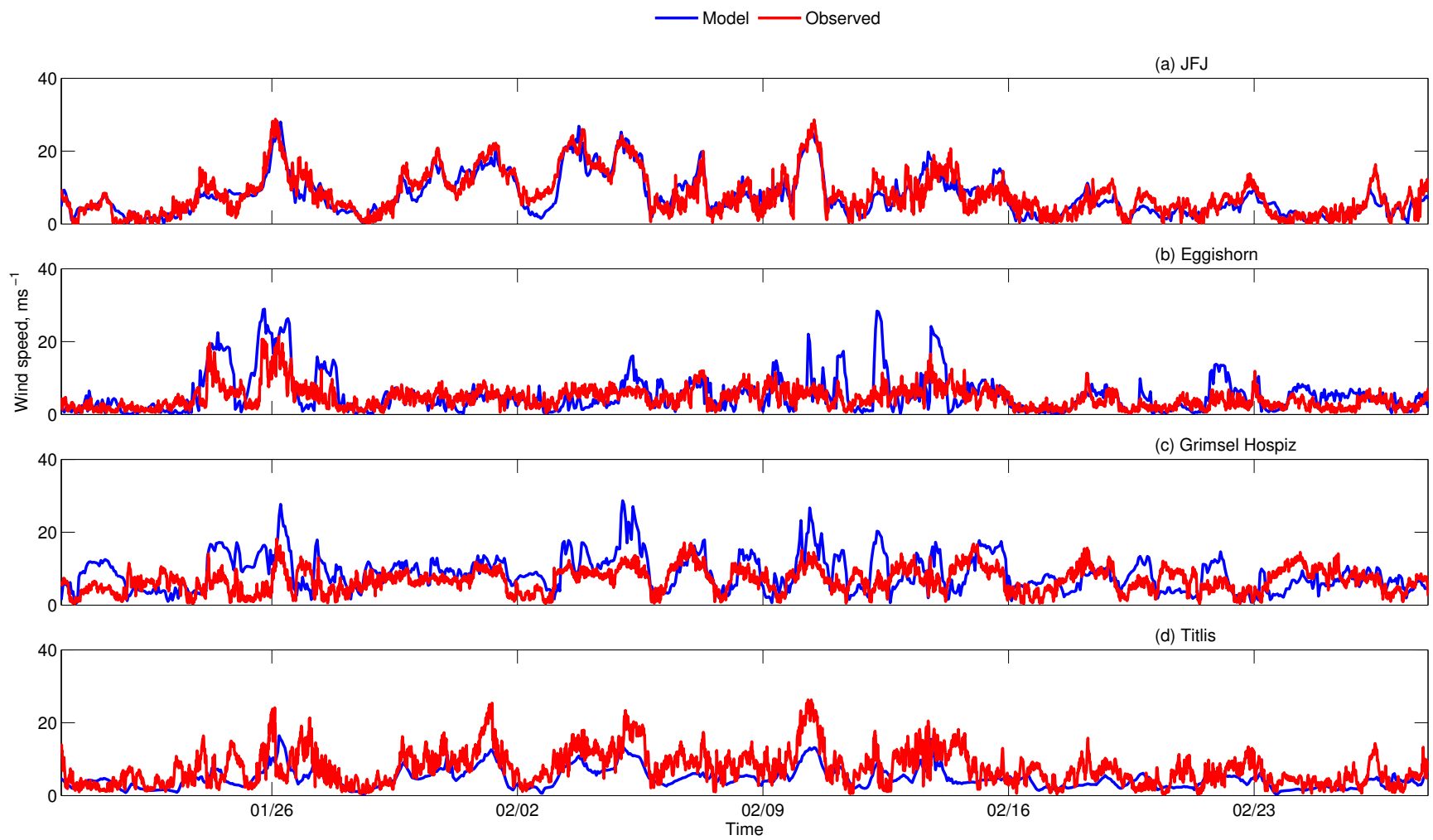

Figure 4. A comparison of the wind speed at four MeteoSwiss observation stations with the WRF control simulation during the INUPIAQ field campaign.

tain enough water in any state to represent the LWC and IWC measured at Jungfraujoch.

By only increasing the number of INPs calculated by the Cooper parameterisation, the increase in the number of ice crystals in the IN-1 and IN-3 is only due to deposition and condensation freezing. A better representation of the impact of an increased INP concentration on the clouds would be provided by also increasing the contact and immersion parameterisations of Meyers et al. (1992) and Bigg (1953) respectively. However, any increase in the ice concentrations in the model would cause a reduction in LWC due to the Bergeron-Findeisen process. Hence regardless of the freezing parameterisation chosen, any increase in INPs to match the ice concentrations observed at Jungfraujoch would reduce the LWC below the values observed at Jungfraujoch.

The IN-3 WRF simulation implies that concentrations similar to the measured ice number concentrations are not possible in mixed-phase clouds, which is in contrast to the measurements made at Jungfraujoch. However, as multiple ice and liquid probes from different field campaigns agree on the presence of both high ice and liquid water contents at Jungfraujoch (Choularton et al., 2008; Targino et al., 2009; Lloyd et al., 2015), the correct explanation for the observed ice number concentrations at Jungfraujoch is unlikely to be exclusively dependant on the INP concentration.

\section{Validation of mixed-phase cloud at Jungfraujoch}

To confirm that mixed-phase clouds are possible at Jungfraujoch with the both the measured and modelled ice number concentrations, we used the conditions for the existence of mixed-phase clouds derived by Korolev and Mazin (2003). In their paper, Korolev and Mazin (2003) provide an updraught speed threshold, above which mixed-phase conditions in a cloud can be maintained by the updraught speed. The threshold is based on the assumptions of a parcel model, and that a cloud must be water saturated for droplets to exist in clouds. The threshold updraught speed is defined by the following:

$u_{z, t}=\frac{b_{\mathrm{i}}^{*} N_{\mathrm{i}} \bar{r}_{\mathrm{i}}}{a_{0}}$,

where $N_{\mathrm{i}}$ is the number concentration of ice crystals, $\bar{r}_{\mathrm{i}}$ is the mean radius of ice crystals, and $a_{0}$ and $b_{i}^{*}$ are thermodynamic variables dependant on the pressure and temperature of the parcel, as defined in Korolev and Mazin (2003).

The threshold updraught speed was calculated for both the measured and modelled ice concentrations. For the measured ice concentrations, the term $N_{\mathrm{i}} \bar{r}_{\mathrm{i}}$ was calculated using the 2D-S size distribution, with measurements of temperature and pressure from Jungfraujoch also used to calculate $u_{z, t}$. The vertical wind speed measured by the sonic anemometer at Jungfraujoch was then compared to $u_{z, t}$. For the modelled 

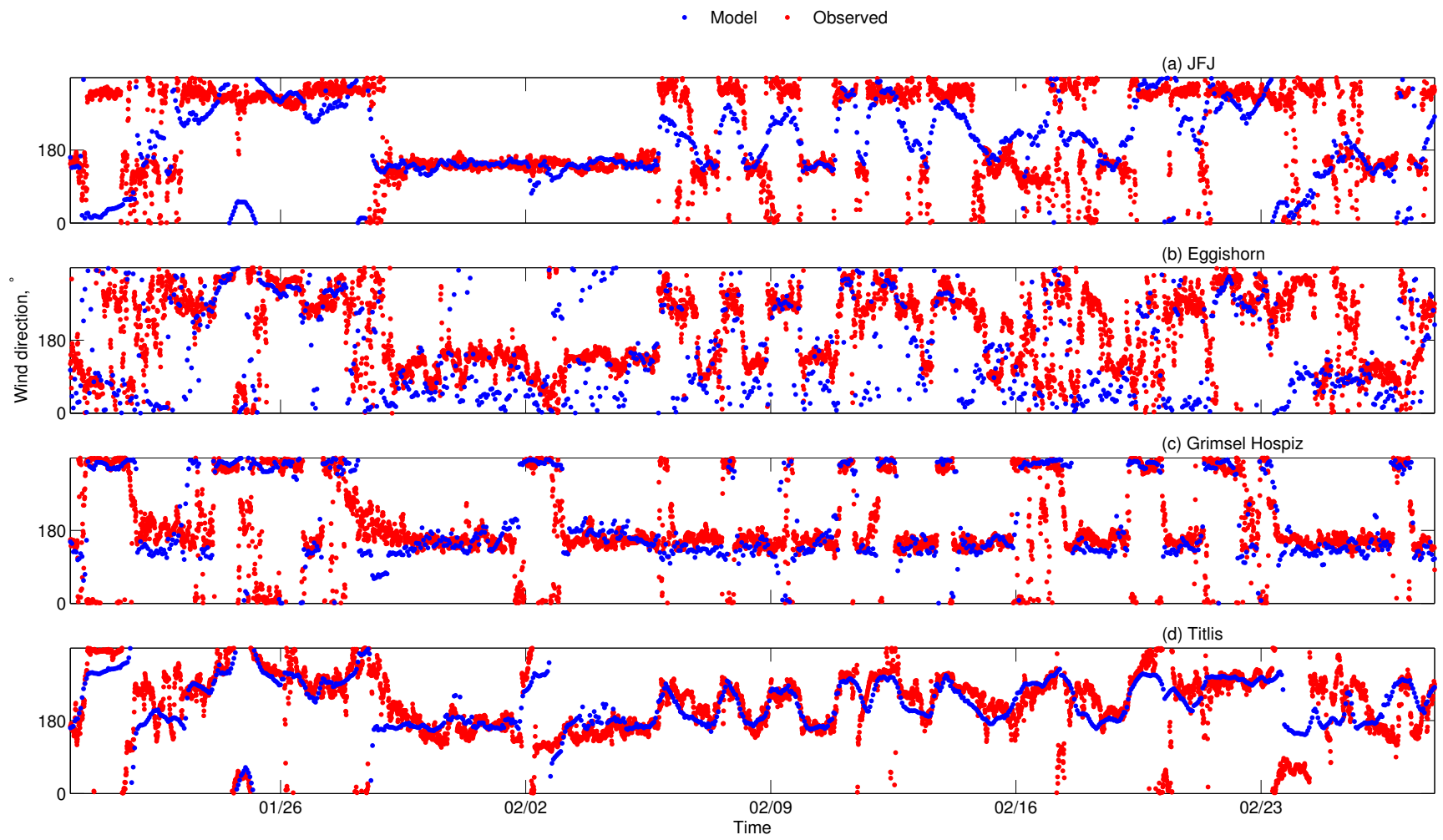

Figure 5. A comparison of the wind direction at four MeteoSwiss observation stations with the WRF control simulation during the INUPIAQ field campaign.

ice concentrations, the term $N_{\mathrm{i}} \bar{r}_{\mathrm{i}}$ was calculated from the first moment of the ice, snow and graupel size distributions from the control and IN-3 WRF simulations, using the gamma size distribution parameters from the Morrison scheme (see Appendix of Morrison et al., 2005). The snow and graupel size distributions are included in the calculation, as the growth of both snow and graupel also depletes the LWC through the Bergeron-Findeisen process. Additionally, the simulated temperature and pressure from each simulation were used in the calculation of $u_{z, t i}$, which was then compared with the simulated vertical wind speed from the two simulations.

For the majority of the campaign, the vertical wind speed measured at Jungfraujoch was greater than the threshold updraught speed for mixed-phase cloud conditions (Fig. 7), which is consistent with the coexistence of liquid water and ice crystals witnessed at Jungfraujoch. Assuming that the atmosphere is saturated with respect to liquid, the updraught threshold reinforces the measurements in suggesting that droplets and ice can coexist in clouds at Jungfraujoch, as indicated by the 2D-S and CDP measurements in Fig. 6.

For the control WRF simulation, Fig. 7 shows the low ice concentrations significantly reduce $u_{z, t}$, such that the updraught threshold is close to zero, which is lower than the simulated values of $u_{z}$ at Jungfraujoch when updraughts are present in the model. When the INP concentrations in the WRF model are increased, more ice crystals are produced, which is caused by vapour deposition onto the additional INPs. The vapour deposition results in a reduction of the saturation ratio in the model. To maintain a saturation ratio which is greater than liquid saturation, a greater updraught speed is required. Hence increasing the INP concentration in WRF increases the updraught speed threshold for the existence of mixed-phase clouds.

Figure 7 indicates that when the INP concentrations are increased, the updraught speed threshold increases to values close to $u_{z}$ in the periods where updraughts are modelled at Jungfraujoch. During some periods, the simulated vertical wind speed is lower than the updraught speed threshold from the IN-3 simulation. During other periods, there is no updraught present, which would prevent mixed-phase conditions from being sustained. As the updraught speed is either lower than the threshold during these periods or not present at all, the Korolev and Mazin analysis predicts that mixedphase clouds will not occur during these periods. The analysis supports the findings of the IN-3 simulation indicated in Fig. 6a and $b$.

A limitation of using the model to assess if mixed-phase clouds can exist is the difference between the simulated and observed vertical wind speed. Figure 7 shows that the observed vertical wind speed generally has significantly higher updraught velocities than the model, and shows an apparent absence of the downdrafts, which are simulated in the 
(a)
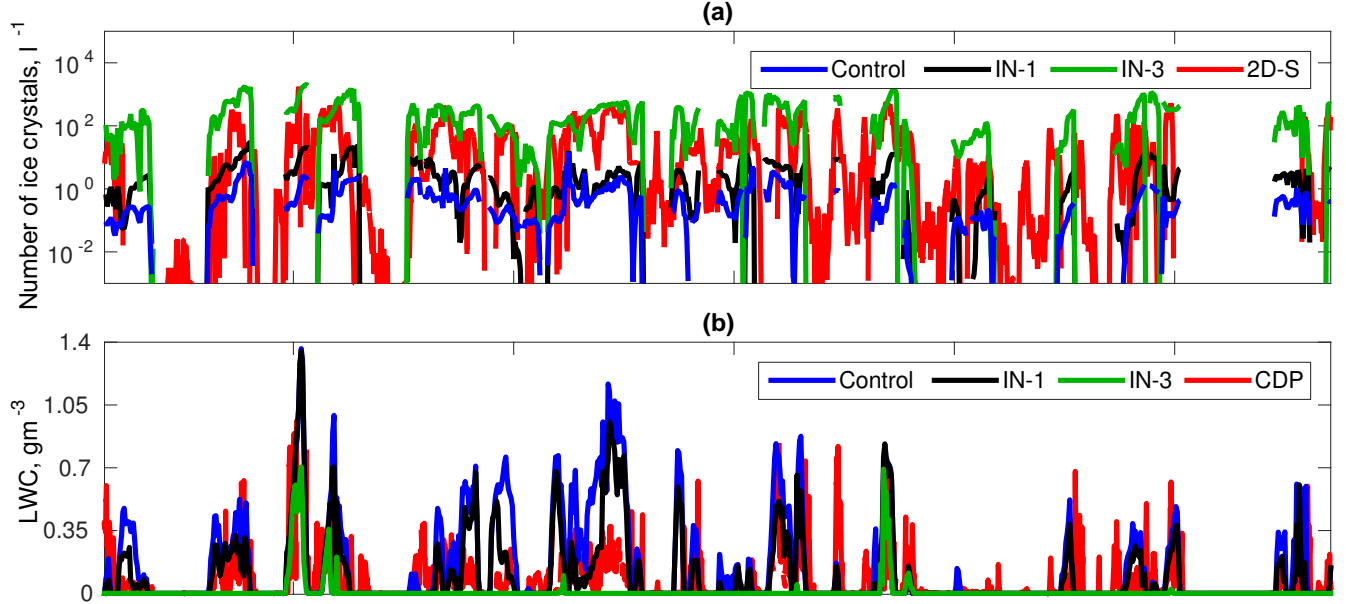

(c)

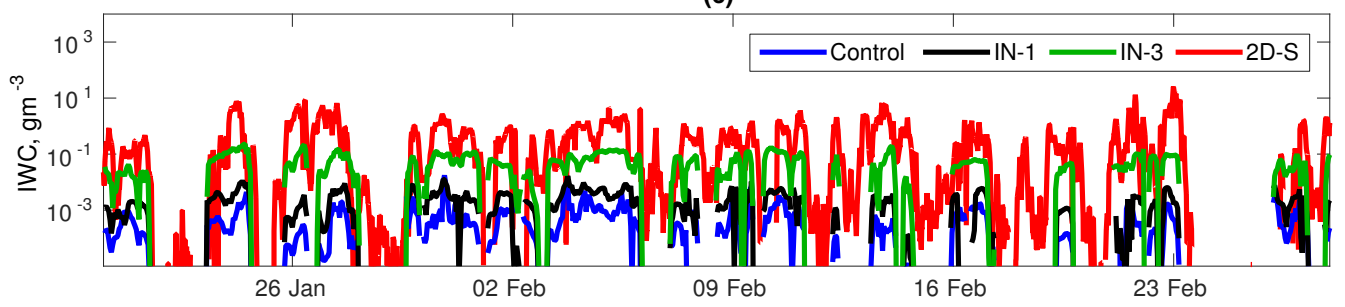

Figure 6. (a) Comparison of 2D-S ice number concentration measured at Jungfraujoch during the INUPIAQ campaign with the ice number concentration from the control, IN-1 and IN-3 WRF model simulations. (b) Comparison of the CDP LWC measured at Jungfraujoch during the INUPIAQ campaign with the LWC from the control, IN-1 and IN-3 WRF model simulations. (c) Comparison of IWC inferred from 2D-S measurements at Jungfraujoch during the INUPIAQ campaign with the IWC from the control, IN-1 and IN-3 WRF model simulations.

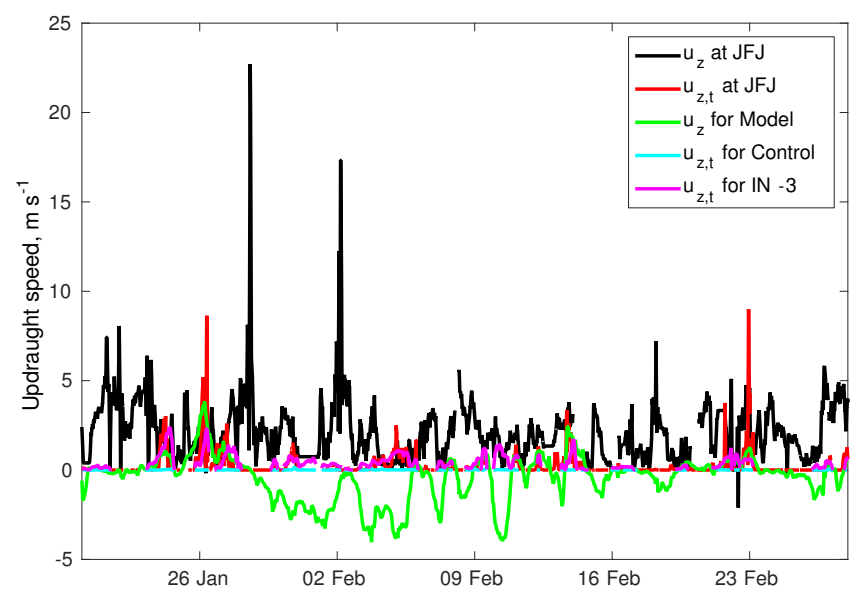

Figure 7. Analysis of vertical wind speed $u_{z}$ with the updraught threshold required for the presence of mixed-phase cloud for both measurements at Jungfraujoch and the control and IN-3 simulations. The updraught threshold is calculated as defined by Eq. (2), which is adapted from Korolev and Mazin (2003).

model during the campaign. However, the resolution of the model causes the vertical wind speed outputs to represent a $1 \mathrm{~km}$ horizontal area at the surface of the model. In reality, the $1 \mathrm{~km}$ area surrounding Jungfraujoch contains very steep orography that cannot be accurately represented in the model. The actual terrain causes strong updraughts to blow up the steep slopes below Jungfraujoch, which cannot be fully represented in the model. Hence the simulated vertical velocities may not accurately represent the vertical speeds observed at Jungfraujoch and may limit the usefulness of comparing vertical speeds and updraught thresholds from the model simulation to assess whether mixed-phase clouds can occur.

Nonetheless, the absence of the observed mixed-phase clouds in the IN-3 simulation implies that increasing the IN concentration alone cannot explain the measured ice number concentrations at Jungfraujoch. Results from our modelling suggest additional processes are important in the production of ice in orographic mixed-phase clouds.

\subsection{Hallett-Mossop process upwind of Jungfraujoch}

Ice multiplication processes such as the Hallett-Mossop process (Hallett and Mossop, 1974) have been suggested as an important mechanism in the production of ice crystals in mixed-phase clouds. Rogers and Vali (1987) suggested in their study at Elk Mountain that the Hallett-Mossop is not responsible for the increased ice number concentrations as the droplet sizes are not sufficiently large enough to cause splinter production. In addition they suggested that temper- 
atures witnessed at Elk Mountain are outside the HallettMossop temperature range of -3 to $-8^{\circ} \mathrm{C}$. During the INUPIAQ campaign, the temperatures observed at Jungfraujoch were generally colder than $-8^{\circ} \mathrm{C}$, ruling out secondary ice production at the site via the Hallett-Mossop process (Lloyd et al., 2015). However, Targino et al. (2009) suggested that as Jungfraujoch is generally above cloud base, the HallettMossop process could occur below Jungfraujoch at higher temperatures, and that splinters could be lifted from the cloud base to increase ice number concentrations at the summit. For secondary ice production to occur at cloud base, supercooled liquid water and ice crystals must both be present. In addition, the temperature at cloud base must be within the Hallett-Mossop temperature range, and a strong updraught must be present to advect the newly produced splinters towards Jungfraujoch.

To establish if splinters were transported to Jungfraujoch from cloud base, back trajectories were calculated using the WRF control simulation output. By assuming the wind field $-u_{i j k}$ at the initial output time was constant along the back trajectory, the back trajectories were calculated.

$\Delta x_{i j k}=-u_{i j k} \Delta t$,

where $\Delta t=30$ is the time step in seconds. At each point along the trajectories, the WRF output fields were interpolated from nearest WRF output variables to the point. Using the LWC $q_{l}$ and ice number concentration $n_{\text {ice }}$, the production rate of splinters formed by the Hallett-Mossop process was calculated.

$\frac{\mathrm{d} n_{\mathrm{i}, \mathrm{hm}}}{\mathrm{d} t}=q_{l} V_{\mathrm{f}} A \eta n_{\mathrm{ice}}$,

with $V_{\mathrm{f}}$ denoting the fall speed of the ice particle, $A$ denoting the area swept out by the ice crystal and $\eta$ the number of splinters produced per $\mu \mathrm{g}$ of rime. $\eta$ is defined as $350 \times 10^{6}$ splinters kg ${ }^{-1}$ following Mossop and Hallett (1974), whilst the ice crystals were assumed to be spherical with diameters of $500 \mu \mathrm{m}$, and falling at $2 \mathrm{~m} \mathrm{~s}^{-1}$. As the model resolution is finite, we define the temperature thresholds within which splinters are produced, conservatively using a slightly wider temperature range than Hallett and Mossop (1974), with the production rate set to 0 if the temperature was greater than $-2{ }^{\circ} \mathrm{C}$ or less than $-10^{\circ} \mathrm{C}$. The extended range was to prevent the splinter concentration being underestimated due to any differences between the constant temperature field in the model and the real temperature. The cumulative number of splinters produced along each back trajectory was then calculated to provide a maximum number of splinters that could be produced along the back trajectory. The calculation of the total concentration of ice splinters along the back trajectory assumes that every ice splinter produced along the back trajectory is transported to Jungfraujoch and measured as an ice crystal, which is unlikely as the ice crystals would be reduced along the back trajectory by sedimentation or collisions with sedimenting particles.

The total number concentration of splinters produced along the back trajectory was added to the ice number concentration at Jungfraujoch and is compared with the ice number concentrations produced by the WRF control run and the 2D-S in Fig. 8.

When including the splinters calculated using Eq. (4), the ice number concentration from the WRF control simulation increases significantly during certain periods of the campaign, as indicated by the grey shaded areas in Fig. 8. For example on 1 February, the addition of splinters increases the WRF ice number concentration to within a factor of 10 of the 2D-S ice number concentration at Jungfraujoch. Figure 9 shows the back trajectory from 1 February 2014 at 19:00 UTC, plotted following the direction of the wind, which was south-easterly.

The high number of splinters calculated along the back trajectory is due to the constant presence of liquid water and ice crystals, in addition to the initial presence of a suitable temperature for splinter production. The simulation of splinters stops when the temperature falls below $-10^{\circ} \mathrm{C}$ after $20 \mathrm{~min}$, producing a significantly larger concentration of ice splinters than simulated at Jungfraujoch in the control simulation. The conditions along the back trajectory suggest that during this case study the WRF model underpredicts the concentration of ice crystals produced by the Hallett-Mossop process quite considerably. Viewing the case in isolation, the inclusion of splinters produced at cloud base in the model would allow a better representation of the ice concentrations observed at Jungfraujoch.

However, as indicated in Fig. 8 the case on 1 February is not representative of the whole campaign, with only small concentrations of splinters simulated upwind of Jungfraujoch throughout most of the campaign. Figure 10 illustrates that on 26 January, where the observed and modelled ice number concentrations differ by 3 orders of magnitude, no splinters are simulated. The absence of secondary ice along the back trajectory is a response to the temperature remaining below $-10{ }^{\circ} \mathrm{C}$ throughout the ascent of the air towards Jungfraujoch, causing no splinters to be produced, despite the presence of both supercooled water and ice crystals. As a result, there is no increase in ice crystal concentration at Jungfraujoch for the 26 January case. Hence, the Hallett-Mossop process occurring below cloud base is not the main reason for the large discrepancy between the measured and modelled ice number concentration during this period.

However, during certain periods splinter production may contribute to the difference between the modelled and measured ice number concentrations. Also, the influence of secondary ice production on the ice concentration in mountainous regions may differ due to seasonal or spatial variations. Secondary ice production may significantly enhance ice number concentrations in regions at different altitudes or at different times of the year, if the temperatures in these re- 


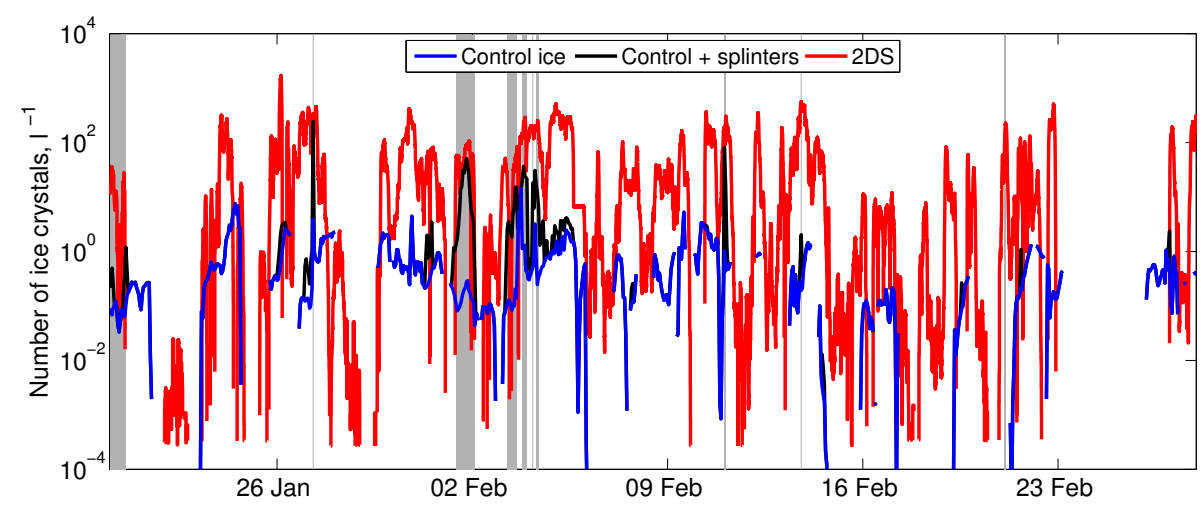

Figure 8. Comparison of ice number concentrations from the WRF control simulation, the control simulation with the addition of rime splinters produced by the Hallett-Mossop process calculated using Eq. (4), and the 2D-S probe at Jungfraujoch during the INUPIAQ campaign. The grey-shaded areas indicate periods where the ice number concentration including the splinters is at least a factor of 10 greater than the concentration from the WRF control simulation.
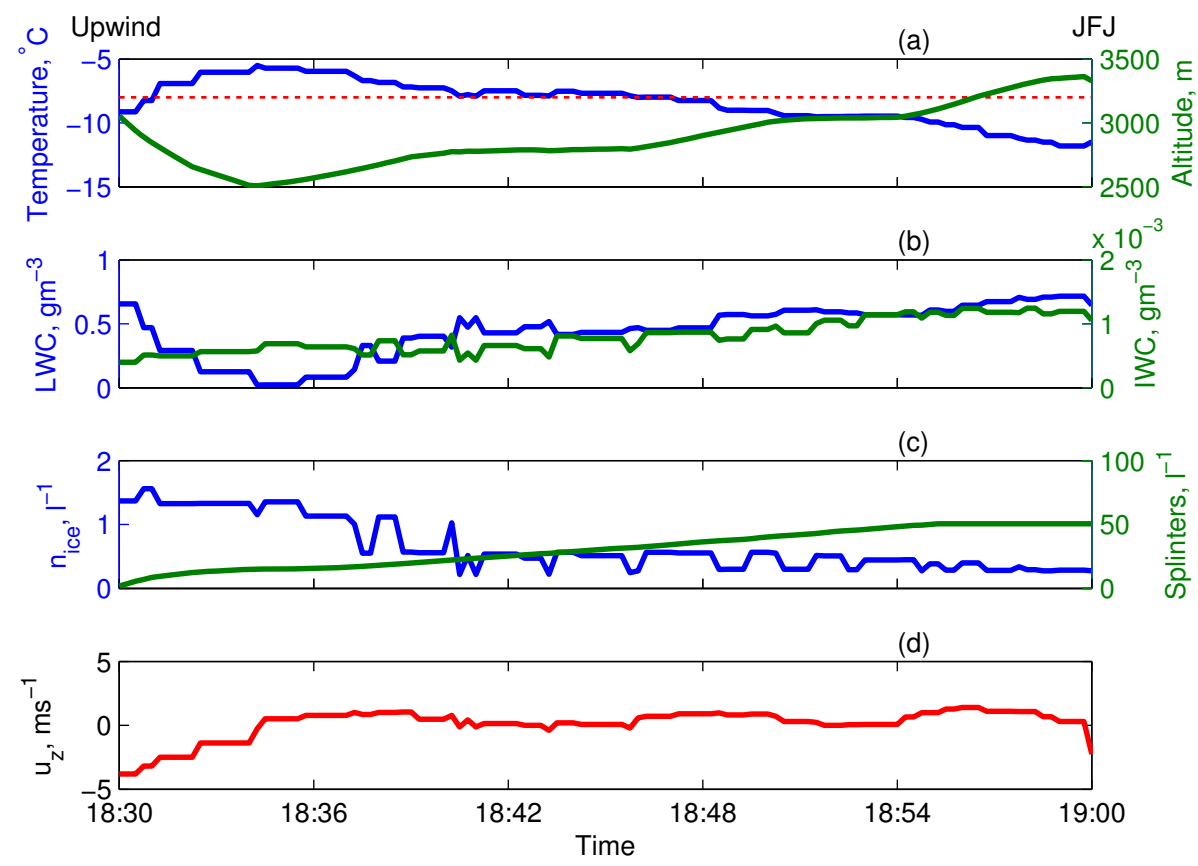

Figure 9. Variations in dynamical and microphysical properties along a back trajectory of air between a point upwind of Jungfraujoch and Jungfraujoch on 1 February 2014, assuming a constant wind field. The constant wind field is taken from the WRF control simulation output of 1 February 2014 at 19:00 UTC. (a) Temperature and altitude along the back trajectory, with the red dashed line illustrating the $-8{ }^{\circ} \mathrm{C}$ isotherm. (b) LWC and IWC along the back trajectory. (c) Ice number concentration from the WRF control run along the back trajectory, and the cumulative number of splinters produced along the trajectory, calculated using Eq. (4). (d) Vertical wind speed along the back trajectory.

gions are more frequently within the Hallett-Mossop temperature regime than witnessed at Jungfraujoch.

\subsection{Inclusion of snow concentration in ice concentration}

The ice number concentration simulated in WRF may be reduced by the misrepresentation of some ice crystals as snow crystals. Ice is converted to snow in the Morrison scheme when ice size distributions grow by vapour diffusion to sizes greater than a threshold mean diameter. The Morrison scheme uses a threshold mean diameter of $125 \mu \mathrm{m}$ following Harrington et al. (1995). However, Schmitt and Heymsfield (2014) implied that the threshold diameter can vary significantly in real clouds, suggesting threshold diameters of 150 and $250 \mu \mathrm{m}$ for two separate case studies. Raising the threshold diameter for autoconversion in the microphysics scheme may provide a simulated ice number concentration which is 

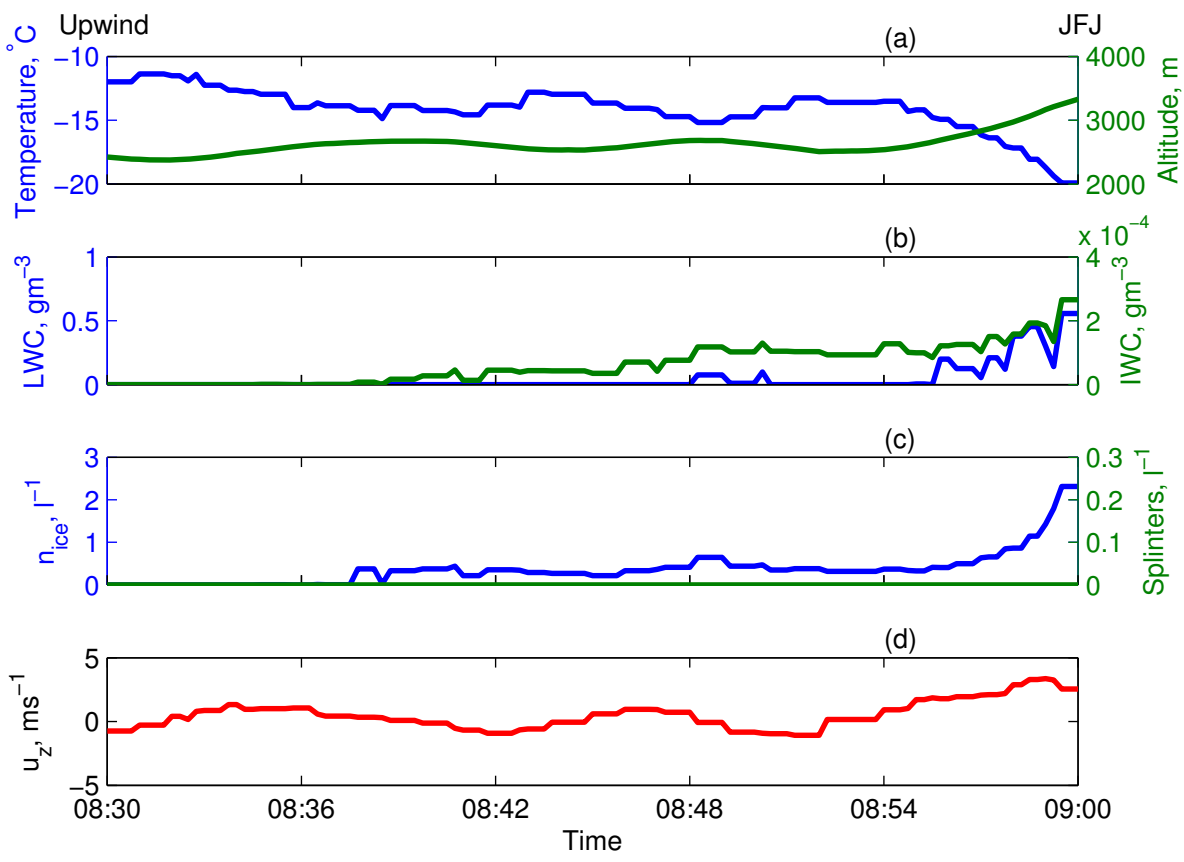

Figure 10. As for Fig. 9 but from the WRF simulation of 26 January 2014 at 09:00 UTC.

more representative of the $2 \mathrm{D}-\mathrm{S}$ measurements at Jungfraujoch.

To assess whether the discrepancy between the measured and modelled ice number concentrations is caused by ice being incorrectly converted to snow, the frozen concentration was calculated by adding the modelled snow and ice number concentrations together. Whilst the snow number concentration will include falling snow in addition to large ice, this is only significant if the frozen concentration is greater than the measured ice number concentration.

The increase in ice number concentration with the addition of snow is not significant enough to match the ice number concentrations observed at Jungfraujoch. Figure 11 suggests the number of snow crystals is small compared to the difference between the modelled and observed ice number concentrations. The inclusion of snow into the ice number concentrations fails to increase the concentrations by the three orders of magnitude required to match the observed concentrations.

\subsection{Flux of crystals from surface}

After careful analysis, Lloyd et al. (2015) suggested that whilst blowing snow influenced ice number concentrations periodically, the effect provided only a minor contribution to the ice number concentration at Jungfraujoch. However, they also suggested that a surface ice generation mechanism was potentially the source of the high ice number concentrations witnessed at Jungfraujoch. Along with Rogers and Vali (1987), they speculated that it was possible for crystals growing on the surface of the mountain to be blown by sur- face winds into the atmosphere and influence the ice number concentration. Furthermore, Vali et al. (2012) found the existence of ground-layer snow clouds, which are clouds found to form close to the surface over snow-covered ground. Vali et al. (2012) suggested that ground-layer snow clouds formed by particles, which could be snow or ice, were being lifted from the surface. The high ice number concentrations observed at Jungfraujoch could be caused by these ground-layer snow clouds, with a flux of surface crystals not represented in the model causing the high ice number concentrations measured.

Ice which forms on snow surfaces is known as surface hoar or hoar frost. Surface hoar forms by deposition of water vapour onto the snow surface in supersaturated air at temperatures below $0{ }^{\circ} \mathrm{C}$ ( $\mathrm{Na}$ and Webb, 2003; Polkowska et al., 2009). Wind also has a significant effect on surface-hoar development, with ideal wind speeds for formation between 1$2 \mathrm{~m} \mathrm{~s}^{-1}$ (Hachikubo and Akitaya, 1997). Stossel et al. (2010) discovered that surface-hoar formation occurs during clear nights with humid air and can survive throughout the day. Previous research has mostly been motivated by understanding avalanche formation, with research focused on the formation (Colbeck, 1988; Hachikubo and Akitaya, 1997; Na and Webb, 2003) and spatial variability of the phenomena (Helbig and Van Herwijnen, 2012; Shea and Jamieson, 2010; Galek et al., 2015). The research into atmospheric impacts of surface hoar have been limited.

However, the atmospheric influence of frost flowers, a similar phenomena to surface hoar, is the subject of much research. Frost flowers are highly saline crystals which form 


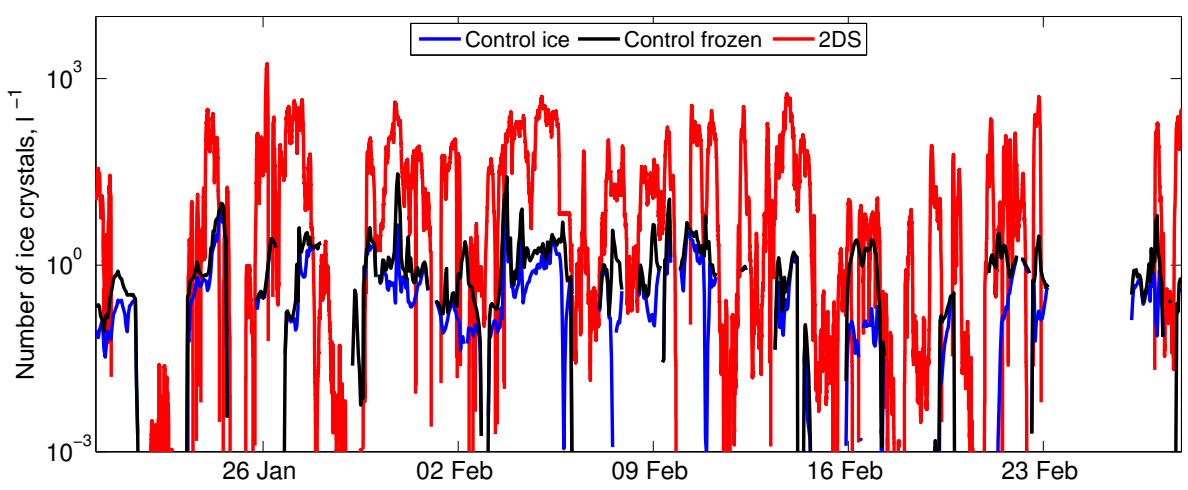

Figure 11. Comparison of measured 2D-S ice number concentration at Jungfraujoch during the INUPIAQ campaign with the ice concentration and the total frozen concentration measured by the control WRF model simulation at Jungfraujoch.

on freshly formed sea ice that is significantly warmer than the atmosphere above (Perovich and Richter-Menge, 1994; Style and Worster, 2009). Similarly to surface hoar, they require the presence of supersaturated air with respect to ice above the surface (Rankin et al., 2002), and grow by vapour deposition (Domine et al., 2005). Atmospheric scientists have shown particular interest in the role of frost flowers in the production of sea salt aerosol in the atmosphere (Rankin and Wolff, 2003; Alvarez-Aviles et al., 2008). $\mathrm{Xu}$ et al. (2013) provided an observation-based parameterisation of the atmospheric flux of aerosol from frost flowers. The parameterisation has an exponential dependency on wind speed and was included in the WRF-Chem model. Xu et al. (2013) found the inclusion of frost flowers in the model enabled a better agreement between modelled and measured sea salt aerosol concentrations. However, it should be noted that frost flowers have been observed to exist at high wind speeds $\left(12 \mathrm{~m} \mathrm{~s}^{-1}\right)$ without the production of aerosol into the atmosphere (Roscoe et al., 2011), leaving uncertainty as to whether aerosols can be blown from frost flowers into the atmosphere.

Similarly, several studies have formulated a flux of blowing snow into the atmosphere. These formulations are generally much more complicated surface-atmosphere models, which have divided the transport of blowing snow into two layers: saltation and turbulent suspension (Lehning et al., 2008; Vionnet et al., 2014). The saltation layer is the movement of blowing snow which is only blown slightly off the surface into the atmosphere before returning to the surface. The turbulent suspension layer includes particles which are transported by the wind without contact with the ground. In Vionnet et al. (2014), the evolution of the number of blowing snow particles in the turbulent suspension layer $N_{\mathrm{S}}$ is modelled using

$$
\begin{aligned}
\frac{\partial N_{\mathrm{s}}}{\partial t}+\underbrace{\boldsymbol{u}_{j} \frac{\partial N_{\mathrm{s}}}{\partial x_{j}}}_{\text {Advection }}=\underbrace{\frac{\partial}{\partial x_{j}}\left(\overline{N_{\mathrm{s}}^{\prime} \boldsymbol{u}_{j}^{\prime}}\right)}_{\text {Turbulence }}+\underbrace{\frac{\partial}{\partial x_{j}}\left(N_{\mathrm{s}} V_{N} \delta_{j s}\right)}_{\text {Sedimentation }} \\
+\underbrace{S_{N}}_{\text {Sublimation }},
\end{aligned}
$$

where $\boldsymbol{u}$ is the $3-\mathrm{D}$ wind vector, $V_{N}$ represents the particle fall speed, and $S_{N}$ is sublimation sink. Vionnet et al. (2014) also determined when blowing snow was transferred between the surface, saltation layer, suspension layers, and the atmosphere above, by using several coupled models. The derivation of blowing snow in Vionnet et al. (2014) is complicated when compared with the flux of frost flowers used by $\mathrm{Xu}$ et al. (2013), but provides a better representation of lower atmospheric processes.

Whilst the flux is of sea salt aerosol, the flux equation provided by Xu et al. (2013) does not require the definition of either the aerosol concentration or the frost flower density, and essentially provides a flux which is only dependant on wind speed. Feick et al. (2007) suggested that the most important influence on surface-hoar destruction is wind, implying that the crystals on the surface are removed by the wind blowing the crystals into the atmosphere. As the aerosol flux derived by Xu et al. (2013) and the removal of hoar crystals from the surface are both strongly dependent on wind, the flux can be used to model hoar crystals being blown from the surface. The Morrison microphysics scheme includes terms for advection, sedimentation and sublimation, which would influence the ice crystals added by the flux, and represents some of the lower atmosphere processes included in the blowing snow formulation of Vionnet et al. (2014). However, the Morrison microphysics does not include turbulent diffusion effects, which are represented in the blowing snow scheme of Vionnet et al. (2014). Whilst turbulent diffusion is an important influence of surface particle transport, it is difficult to accurately represent turbulence over the relatively large grid spacing in the model in mountainous terrain. 
Nevertheless, the lack of turbulence provides a limitation of the surface ice crystal flux. Additionally, no representation of particles in the saltation layer is included, or the transfer of particles in the saltation layer to or from the atmosphere, which could increase or decrease the number of surface crystals added to the atmosphere.

We adapted the aerosol flux from Xu et al. (2013) for inclusion in our simulations to assess if the discrepancy between modelled and measured ice number concentrations can be found. The surface ice crystal flux was calculated using the following:

$\phi=e^{0.24 u_{\mathrm{h}}-0.84}$,

where $u_{\mathrm{h}}$ is the horizontal wind speed at the surface of the model and $\phi$ is unitless. $\phi$ is then multiplied by a magnitude of crystals per surface area per second to give the surface ice crystal flux. A number of restrictions were applied to the surface ice crystal flux formulation to accurately represent where surface hoar develops and how surface hoar is blown into the atmosphere. To ensure the flux remained only as a surface effect, the flux was applied only to the first level of the model. As surface hoar only grows in the atmosphere when the temperature is below freezing and the air is water saturated (Na and Webb, 2003; Polkowska et al., 2009), the flux is limited to regions where the temperature is less than $0{ }^{\circ} \mathrm{C}$ and the relative humidity is greater than 1 . A minimum horizontal wind speed of $4 \mathrm{~m} \mathrm{~s}^{-1}$ was applied to the flux, as surface hoar forms at $1-2 \mathrm{~m} \mathrm{~s}^{-1}$ (Hachikubo and Akitaya, 1997) and hence crystals are unlikely to be blown into the atmosphere at these wind speeds. To better represent areas where surface hoar forms on the surface, the latent heat flux at the surface has been previously used to model periods of surface-hoar formation (Stossel et al., 2010; Horton et al., 2014). Horton et al. (2014) suggests that surface hoar forms when the latent heat flux to the surface is positive. Using the latent heat flux modelled by the NOAH land-surface model in WRF, we assume that if the latent heat flux towards the surface is positive, then the surface hoar is present to be blown into the atmosphere. Hence the surface ice crystal flux is only active if the latent heat flux is positive. The positive latent heat flux represents the growth of surface hoar, which appears contradictory to the removal of surface hoar by the wind speeds above the wind threshold. However, without accurate measurements of surface hoar to use in the model, the flux of latent heat to the surface allows a representation of where surface hoar is present at the surface of the model. Whilst the latent heat flux provides some indication of the spatial and temporal variations of surface hoar, no dependence on diurnal effects or variations in surface snow cover are included in the flux. The size of the surface hoar crystals was assumed to be $10 \mu \mathrm{m}$. Whilst $10 \mu \mathrm{m}$ is a small size for an ice crystal, the choice of this size is to allow the crystals to remain in the atmosphere, as larger sizes may immediately fall out due to their higher terminal velocities.
Two WRF simulations were run, including the surface crystal flux. The first was Surf-6, which assumed the flux magnitude of $10^{6} \mathrm{~m}^{-2} \mathrm{~s}^{-1}$ following Geever et al. (2005) and $\mathrm{Xu}$ et al. (2013). The flux magnitude assumed in the Surf-6 simulation assumes that the number of surface hoar crystals blown into the atmosphere is equal to the number of frost flowers in Xu et al. (2013), A second simulation (Surf-3) was then run with the flux magnitude reduced to $10^{3} \mathrm{~m}^{-2} \mathrm{~s}^{-1}$. The ice number concentrations, LWC and IWC from the Surf-6 and Surf-3 simulations are compared with the 2D-S ice number concentrations in Fig. 12, with a one-to-one comparison of the Surf-3 and 2D-S ice number concentrations presented in Fig. S3 of the Supplement.

The Surf-6 is in good agreement with the 2D-S, although with higher concentrations in the model than measured at Jungfraujoch. The 2D-S and the Surf-6 WRF simulations generally differ by approximately a factor of 100 throughout the campaign. The increase in concentration is unsurprising, as the flux is adapted from an equation based on aerosol concentrations emitted from frost flowers. As the surface crystal flux is an ice concentration, the magnitude of the flux is likely to be smaller than the magnitude used by Xu et al. (2013), which was for an aerosol concentration. Figure 12a indicates that by reducing the magnitude of the flux, Surf- 3 provides a much better agreement with the ice number concentration measured at Jungfraujoch throughout the campaign.

As the surface crystal flux is high, a large number of small ice crystals are ejected from the surface in the model. These crystals grow rapidly by vapour deposition in ice supersaturated conditions. In order to continue to grow by vapour deposition, the ice crystals scavenge vapour from any droplets present and deplete the liquid water from the model by the Bergeron-Findeisen process. As indicated in Fig. 12b, the LWC in the Surf-6 simulation is scavenged by the ice number concentration and does not agree with the LWC measured by the CDP at Jungfraujoch. The large ice number concentration blown into the atmosphere from the surface rapidly depletes the liquid water at Jungfraujoch in the model, further suggesting the magnitude of the flux in Surf-6 is unrealistic. Figure $12 \mathrm{~b}$ shows that by reducing the flux magnitude, the LWC simulated in Surf-3 compares much better with the CDP than Surf-6, with the differences between the model and measurements no greater than a factor of 3 and, for the most part of the campaign, within a factor of 2 .

Figures 13 and 14 show the ice number concentrations and LWCs from the Surf-3 simulation during a period where both ice and liquid are present at Jungfraujoch. Figure 13 indicates that the ice concentration is heavily increased by the surface ice concentration and that the surface ice is not advected high into the atmosphere. The high surface concentrations support the findings of Rogers and Vali (1987) that ice concentrations aloft were much lower than at the surface. The high LWC close to the surface in Fig. 14 indicates the presence of a strong sustained cloud in the model, which further supports the presence of mixed-phase clouds at Jungfraujoch. 


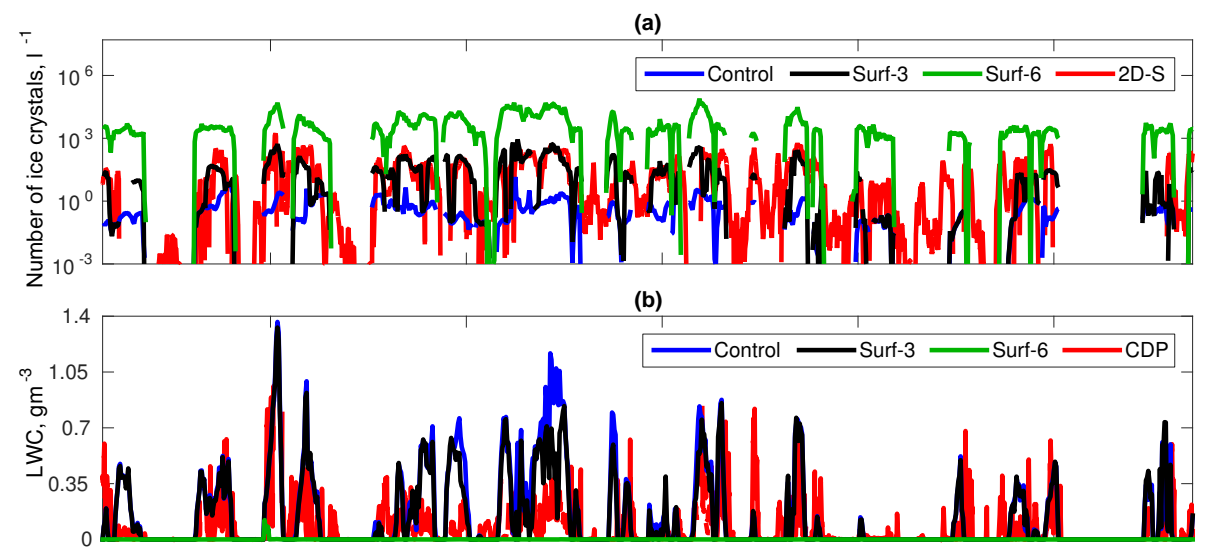

(c)

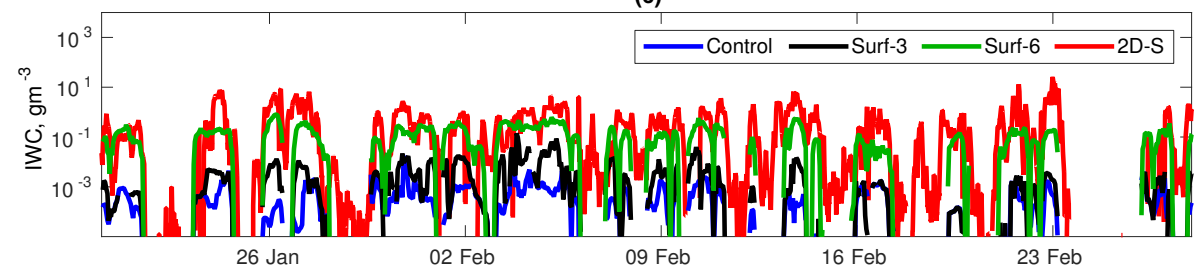

Figure 12. (a) Comparison of measured 2D-S ice number concentration at Jungfraujoch during the INUPIAQ campaign with the concentration from the control WRF model simulation, and the Surf-3 and Surf-6 simulations which included the addition of crystals from a surface flux calculated using Eq. (6). (b) Comparison of measured LWC at Jungfraujoch during the INUPIAQ Campaign with the LWC from the control WRF model simulation, and the Surf-3 and Surf-6 simulations, which included the addition of crystals from a surface flux. (c) Comparison of IWC inferred from 2D-S measurements at Jungfraujoch during the INUPIAQ campaign with the IWC from the control, Surf-3 and Surf-6 WRF model simulations.

In Fig. 12c, the IWC suggests that the inclusion of the surface flux increases the IWC when compared with the control simulation, but does not match the IWC inferred from the 2D-S. Clearly the growth of the advected crystals by vapour deposition in the model is not significant enough to increase the IWC to match the measured IWC at Jungfraujoch. As the number of ice crystals are similar between the model and measurements, the difference in IWC must be due to the assumption that the surface crystals are $10 \mu \mathrm{m}$ in size. As smaller ice crystals contribute less to the IWC than larger particles, an increase in the size of the surface crystals in the model would be required to match the 2D-S inferred IWC, suggesting that the small surface hoar crystals are a limitation of the surface crystal flux parameterisation. However, increasing the size of the ice crystals may rapidly increase the sedimentation of particles, causing fewer ice crystals to be blown from the surface of the model.

One limitation of using a surface crystal flux parameterisation dependent on wind speed is that the modelled ice concentration becomes more dependent on wind speed. Figure 15a indicates that at horizontal wind speeds greater than $4 \mathrm{~m} \mathrm{~s}^{-1}$, there is a strong correlation between the ice concentration simulated in Surf-3 at Jungfraujoch and the simulated wind speed. When compared with the findings of Lloyd et al. (2015, specifically Figs. 16a-d and 17a-d in their paper) and Fig. 15b, the ice crystal concentration in the Surf-3 simu- lation is much more dependent on wind than the 2D-S ice crystal concentrations. The dependency of the Surf-3 simulation on wind speed suggests that the use of a surface flux in the model does not accurately represent the observed ice concentrations and that a flux dependant on wind speed may not be the cause of the ice concentrations at Jungfraujoch. However, as the horizontal wind speeds in the Surf-3 simulation are simulated at a $1 \mathrm{~km}$ resolution, the simulation cannot accurately represent the localised turbulent flow over the mountainous terrain. The turbulent flow close to the surface differs from the representation of wind in the WRF model, and may cause the ice concentration to be less dependent on the larger-scale horizontal wind, even if the surface ice crystal flux is dependent on horizontal wind. To better assess whether a surface ice crystal flux is causing the high ice concentrations observed at Jungfraujoch, an improved representation of small-scale turbulent flow is required in the WRF model or the surface ice crystal flux.

Additionally, the surface crystal flux is independent of the surface concentration of surface hoar crystals. As the surface of the mountains upwind of Jungfraujoch will vary in distribution of surface hoar crystals present on the surface, the flux will vary dependent on the distribution of surface hoar crystals, in addition to the wind speed. Whilst some spatial and temporal variation is provided by the condition that surface hoar only exists in the model when the surface latent heat flux 

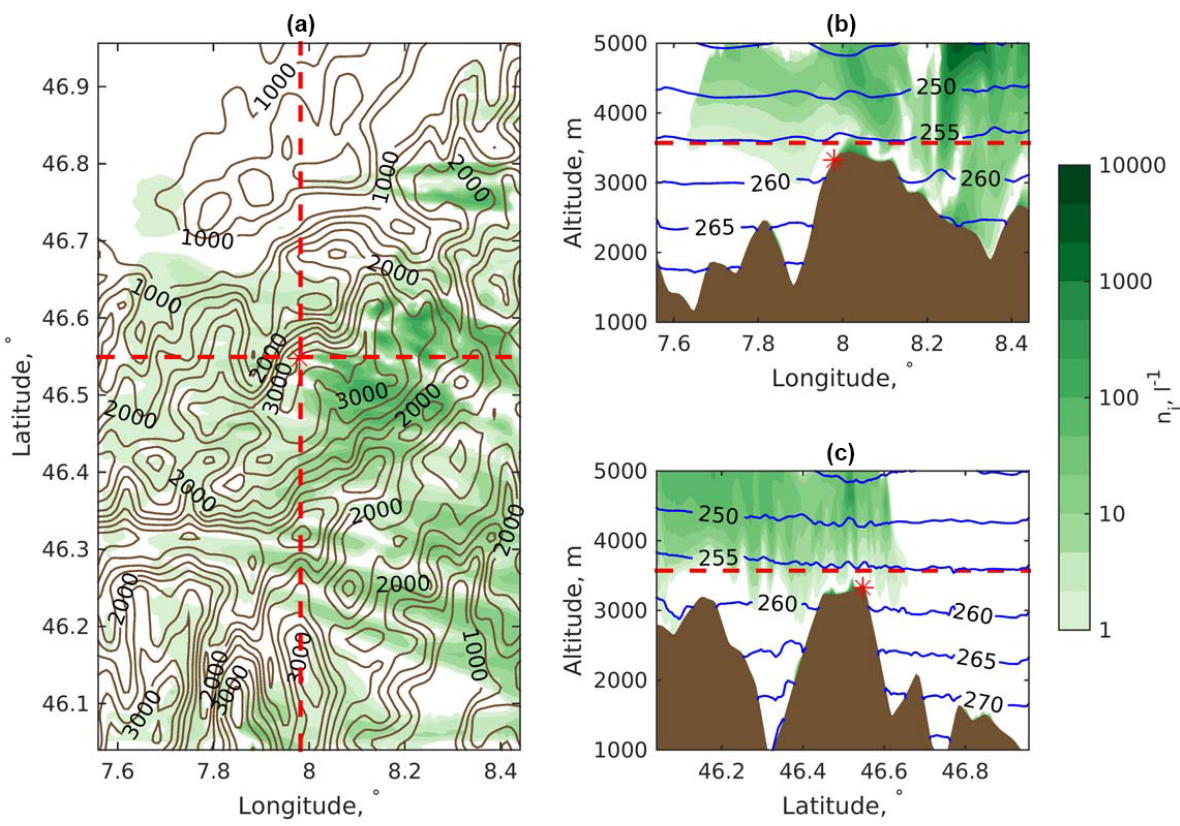

Figure 13. Ice number concentrations at 20:00 UTC on 13 February 2014 from the WRF model simulations, including the addition of crystals from the surface crystal flux in three views. Panel (a) represents a horizontal cross section at the height of Jungfraujoch in reality (3570 m a.s.1.), with the red dashed lines representing the vertical cross sections in panels (b) and (c). Panel (b) represents an east-west vertical cross section at $46.55^{\circ}$ latitude, with red dashed line indicating the horizontal cross section in panel (a), and blue contours indicating isotherms in kelvin. Panel (c) represents a north-south vertical cross section at $7.98^{\circ}$ longitude, with red dashed line indicating the horizontal cross section in panel (a), and blue contours indicating isotherms in kelvin. In all three panels the location of Jungfraujoch is represented by the red star. The prevailing wind direction is north-westerly.
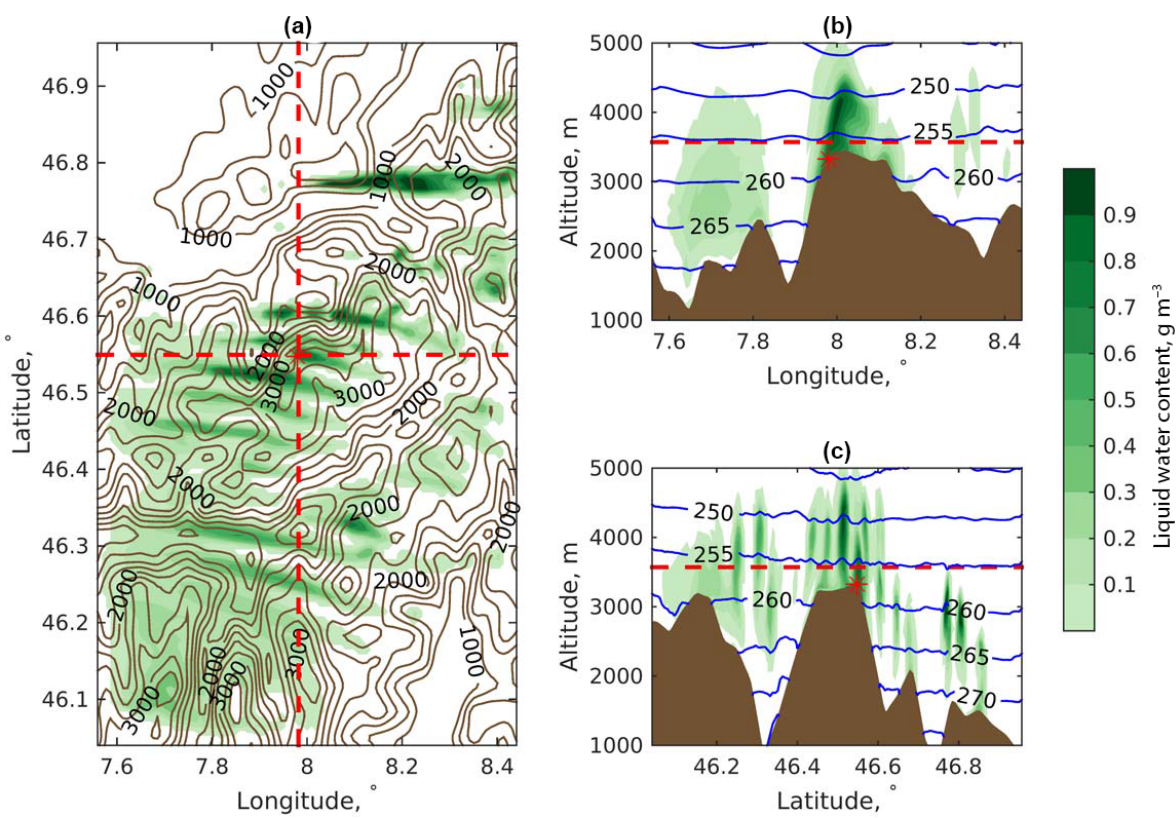

Figure 14. As Fig. 13 except for LWC at 20:00 UTC on 13 February 2014. 

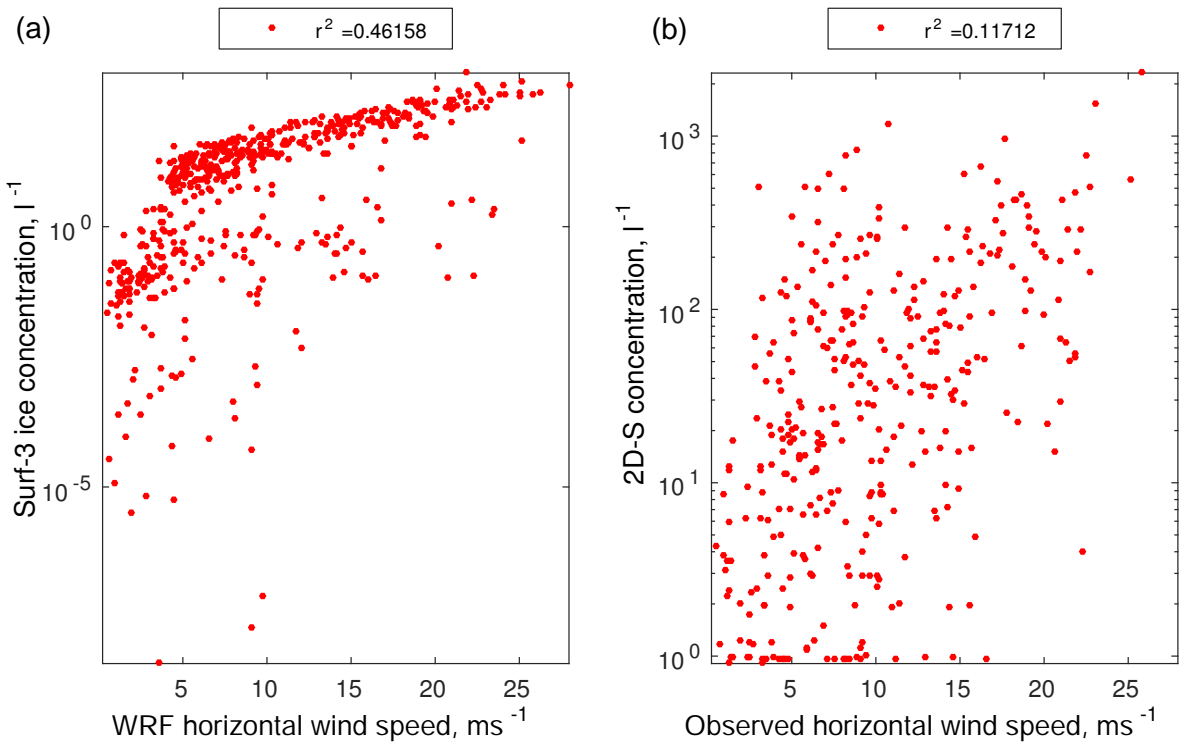

Figure 15. A comparison of the wind simulated in the Surf-3 simulation with (a) the ice crystal concentration simulated in the Surf-3 simulation at Jungfraujoch, and (b) the 2D-S ice crystal concentration at Jungfraujoch.

is positive, the spatial and temporal variations of surface hoar suggested by Stossel et al. (2010) would need to be included in the parameterisation to better represent the surface crystal flux. Also, whilst the magnitude of the flux is calibrated based on our results, the surface crystal flux is adapted from an aerosol flux. To accurately assess the magnitude of the flux, measurements of surface crystal flux would be required to improve the physical understanding of the process of the advection of hoar crystals into the cloud.

Nonetheless, the results of the Surf-3 simulation suggest that the aerosol flux of Xu et al. (2013) can be adapted into a surface crystal flux and used in WRF simulations. The Surf-3 simulation suggests that the inclusion of a surface crystal flux are in good agreement with measured ice number concentrations without depleting the LWC from the model, as was observed at Jungfraujoch. The Surf-3 simulation suggest that the mixed-phase clouds observed at Jungfraujoch are influenced by a surface ice flux mechanism that enhances the ice concentration, similar to the ground-layer snow clouds witnessed by Vali et al. (2012). The results also support the suggestions of Lloyd et al. (2015), proposing that surface hoar could be the source of the ice crystals at Jungfraujoch. However, an improved representation of particle size, distribution and the turbulent effects on the surface crystal flux is required to fully understand the cause of the high ice concentrations observed at Jungfraujoch.

\section{Conclusions}

In this paper, ice number concentrations from WRF model simulations were compared with ice number concentrations measured in orographic clouds of Jungfraujoch during the
INUPIAQ campaign. The ice number concentrations simulated in the model were significantly lower than the concentrations measured in situ, which showed similarly high ice number concentrations to the concentrations witnessed in orographic clouds in previous field campaigns (Rogers and Vali, 1987; Targino et al., 2009). Suggestions for the high ice number concentrations witnessed in orographic clouds were explored using the model simulations.

Whilst increasing INP concentrations in the model produced a better representation of the observed ice number concentrations, the removal of liquid water from the model caused by the increased INP concentrations suggested that greater INP concentrations in the model would prevent the existence of the mixed-phase clouds witnessed at Jungfraujoch. Mixed-phase clouds are regularly witnessed at Jungfraujoch (Choularton et al., 2008; Lloyd et al., 2015), hence an accurate representation of LWC is required to understand the formation and influence of these orographic clouds. Our simulations suggest that whilst additional primary ice nucleation may contribute to ice concentrations in orographic clouds, increasing the INP concentration is not likely to be responsible for the high ice number concentrations observed.

Previous literature also suggested secondary ice production might contribute to an increased ice number concentration in orographic clouds. During the INUPIAQ campaign temperatures observed were outside the temperature range suggested by Hallett and Mossop (1974), implying ice multiplication was not responsible for increasing ice number concentrations. Following Targino et al. (2009), we analysed whether splinter production could occur close to cloud base and be blown into the cloud, and found, using back trajecto- 
ries, that splinter concentrations only infrequently matched observed ice number concentrations. Whilst secondary ice production may be important in orographic clouds at warmer temperatures, secondary ice appears to have only a limited influence on the ice number concentrations observed during the INUPIAQ field campaign.

To evaluate if a flux of surface crystals influenced the ice concentrations in the orographic clouds at Jungfraujoch, a flux of hoar crystals from the surface was adapted from a frost flower aerosol flux and introduced into the WRF model. The inclusion of the flux provided a good agreement with the ice number concentrations measured at Jungfraujoch, suggesting the existence of such a flux may explain why surface measurements are higher than aircraft measurements of ice number concentration witnessed by Rogers and Vali (1987). However, when compared with the wind speed, the modelled concentration retained a dependence on horizontal wind speed not observed for the observed concentrations in Lloyd et al. (2015). The surface crystal flux parameterisation included in our simulations is a simple parameterisation, and small-scale turbulence is not represented in either the model or the parameterisation, which could reduce the influence of wind speed on the modelled concentrations. Also, the parameterisation is independent of the surface concentration of surface hoar crystals. The inclusion of spatial and temporal variations of surface hoar suggested by Stossel et al. (2010) in the parameterisation is required to improve the accuracy of the surface flux. Nevertheless, the surface crystal flux parameterisation in this paper provides a good comparison with the observed ice number concentrations. Following Vali et al. (2012) and Lloyd et al. (2015), we suggest that ice concentrations in orographic clouds over snow surfaces are heavily influenced by a flux of surface crystals into the clouds.

Whilst aerosols acting as INPs are important in initiating the production of ice in orographic clouds, they alone cannot explain the high ice number concentrations observed. There remains uncertainty on the exact causes of the high ice number concentrations in orographic clouds; however, we suggest the uncertainty may be accounted for by a flux of surface crystals from the surface of the mountain. To verify the influence of a flux of surface crystals on orographic clouds, observations and measurements of the flux are required. If the measurements confirm the effect, an improved representation of the flux can be provided using the new data set and can be verified with the current field measurements.

\section{Data availability}

The data from this project can be obtained by contacting the authors of this article.

\section{The Supplement related to this article is available online} at doi:10.5194/acp-16-4945-2016-supplement.
Acknowledgements. The authors wish to express gratitude to colleagues from KIT, MPIC, PSI and the University of Frankfurt, who worked as part of CLACE 2014, for their support and assistance prior to and during the field campaign, and to the staff at Jungfraujoch for access to their site, their assistance and cooperation with our research. The lead author also wished to thank colleagues at the University of Manchester for their support and assistance. The INUPIAQ campaign is supported by a NERC standard grant award NE/K006002/1, whilst the lead author is supported by a NERC studentship and CASE funding from the UK Met Office.

Edited by: C. Hoose

\section{References}

Albrecht, B. A.: Aerosols, cloud microphysics, and fractional cloudiness, Science, 245, 1227-1230, doi:10.1126/science.245.4923.1227, 1989.

Alvarez-Aviles, L., Simpson, W. R., Douglas, T. A., Sturm, M., Perovich, D., and Domine, F.: Frost flower chemical composition during growth and its implications for aerosol production and bromine activation, J. Geophys. Res.-Atmos., 113, 1-10, doi:10.1029/2008JD010277, 2008.

Ansmann, A., Tesche, M., Althausen, D., Müller, D., Seifert, P., Freudenthaler, V., Heese, B., Wiegner, M., Pisani, G., Knippertz, P., and Dubovik, O.: Influence of Saharan dust on cloud glaciation in southern Morocco during the Saharan Mineral Dust Experiment, J. Geophys. Res., 113, D04210, doi:10.1029/2007JD008785, 2008.

Atkinson, J. D., Murray, B. J., Woodhouse, M. T., Whale, T. F., Baustian, K. J., Carslaw, K. S., Dobbie, S., O'Sullivan, D., Malkin, T. L., and O'Sullivan, D.: The importance of feldspar for ice nucleation by mineral dust in mixed-phase clouds, Nature, 498, 355-358, doi:10.1038/nature12278, 2013.

Baltensperger, U., Gäggeler, H. W., Jost, D. T., Lugauer, M., Schwikowski, M., Weingartner, E., and Seibert, P.: Aerosol climatology at the high-alpine site Jungfraujoch, Switzerland, J. Geophys. Res., 102, 19707-19715, doi:10.1029/97JD00928, 1997.

Baltensperger, U., Schwikowski, M., Jost, D. T., Nyeki, S., Gäggeler, H. W., and Poulida, O.: Scavenging of atmospheric constituents in mixed phase clouds at the high-alpine site Jungfraujoch part I: Basic concept and aerosol scavenging by clouds, Atmos. Environ., 32, 3975-3983, doi:10.1016/S13522310(98)00051-X, 1998.

Barstad, I., Grabowski, W. W., and Smolarkiewicz, P. K.: Characteristics of large-scale orographic precipitation: Evaluation of linear model in idealized problems, J. Hydrol., 340, 78-90, doi:10.1016/j.jhydrol.2007.04.005, 2007.

Bigg, E. K.: The formation of atmospheric ice crystals by the freezing of droplets, Q. J. Roy. Meteor. Soc., 79, 510-519, doi:10.1002/qj.49707934207, 1953.

Boucher, O., Randall, D., Artaxo, P., Bretherton, C., Feingold, G., Forster, P., Kerminen, V.-M. V.-M., Kondo, Y., Liao, H., Lohmann, U., Rasch, P., Satheesh, S. K., Sherwood, S., Stevens, B., Zhang, X. Y., and Zhan, X. Y.: Clouds and Aerosols, in: Climate Change 2013: The Physical Science Basis. Contribution 
of Working Group I to the Fifth Assessment Report of the Intergovernmental Panel on Climate Change, edited by: Stocker, T., Qin, D., Plattner, G.-K., Tignor, M., Allen, S., Boschung, J., Nauels, A., Xia, Y., Bex, V., and Midgley, P., Cambridge University Press, Cambridge, UK, New York, NY, USA, 571-657, doi:10.1017/CBO9781107415324.016, 2013.

Broadley, S. L., Murray, B. J., Herbert, R. J., Atkinson, J. D., Dobbie, S., Malkin, T. L., Condliffe, E., and Neve, L.: Immersion mode heterogeneous ice nucleation by an illite rich powder representative of atmospheric mineral dust, Atmos. Chem. Phys., 12, 287-307, doi:10.5194/acp-12-287-2012, 2012.

Brown, P. R. A. and Francis, P. N.: Improved Measurements of the Ice Water Content in Cirrus Using a Total-Water Probe, J. Atmos. Ocean. Tech., 12, 410-414, doi:10.1175/15200426(1995)012<0410:IMOTIW>2.0.CO;2, 1995.

Cannon, D. J., Kirshbaum, D. J., and Gray, S. L.: A mixed-phase bulk orographic precipitation model with embedded convection, Q. J. Roy. Meteor. Soc., 140, 1997-2012, doi:10.1002/qj.2269, 2014.

Chou, C., Stetzer, O., Weingartner, E., Jurányi, Z., Kanji, Z. A., and Lohmann, U.: Ice nuclei properties within a Saharan dust event at the Jungfraujoch in the Swiss Alps, Atmos. Chem. Phys., 11, 4725-4738, doi:10.5194/acp-11-4725-2011, 2011.

Chou, M.-D. and Suarez, M. J.: A Solar Radiation Parameterization for Atmospheric Studies, Technical Report Series on Global Modeling and Data Assimilation, edited by: Suarez, M. J., NASA/TM-1999-104606, available at: http://gmao.gsfc. nasa.gov/pubs/docs/Chou136.pdf (last access: 20 January 2016), 1999.

Choularton, T. W., Bower, K., Weingartner, E., Crawford, I., Coe, H., Gallagher, M. W., Flynn, M., Crosier, J., Connolly, P., Targino, A., Alfarra, M. R., Baltensperger, U., Sjogren, S., Verheggen, B., Cozic, J., and Gysel, M.: The influence of small aerosol particles on the properties of water and ice clouds, Faraday Discussions, 137, 205-222, doi:10.1039/b702722m, 2008.

Colbeck, S. C.: On the micrometeorology of surface hoar growth on snow in mountainous area, Bound.-Lay. Meteorol., 44, 1-12, doi:10.1007/BF00117290, 1988.

Conen, F., Rodrìguez, S., Hüglin, C., Henne, S., Herrmann, E., Bukowiecki, N., and Alewell, C.: Atmospheric ice nuclei at the high-altitude observatory Jungfraujoch, Switzerland, Tellus B, 67, 1-10, 2015.

Connolly, P. J., Flynn, M. J., Ulanowski, Z., Choularton, T. W., Gallagher, M. W., and Bower, K. N.: Calibration of the Cloud Particle Imager Probes Using Calibration Beads and Ice Crystal Analogs: The Depth of Field, J. Atmos. Ocean. Tech., 24, 18601879, doi:10.1175/JTECH2096.1, 2007.

Connolly, P. J., Möhler, O., Field, P. R., Saathoff, H., Burgess, R., Choularton, T., and Gallagher, M.: Studies of heterogeneous freezing by three different desert dust samples, Atmos. Chem. Phys., 9, 2805-2824, doi:10.5194/acp-9-2805-2009, 2009.

Conway, H. and Raymond, C. F.: Snow stability during rain, J. Glaciol., 39, 635-642, 1993.

Cooper, W. A.: Ice Initiation in Natural Clouds, Meteor. Mon., 21, 29-32, doi:10.1175/0065-9401-21.43.29, 1986.

Crosier, J., Bower, K. N., Choularton, T. W., Westbrook, C. D., Connolly, P. J., Cui, Z. Q., Crawford, I. P., Capes, G. L., Coe, H., Dorsey, J. R., Williams, P. I., Illingworth, A. J., Gallagher, M. W., and Blyth, A. M.: Observations of ice multiplication in a weakly convective cell embedded in supercooled mid-level stratus, Atmos. Chem. Phys., 11, 257-273, doi:10.5194/acp-11-257-2011, 2011.

Cziczo, D. J., Froyd, K. D., Hoose, C., Jensen, E. J., Diao, M., Zondlo, M. A., Smith, J. B., Twohy, C. H., and Murphy, D. M.: Clarifying the dominant sources and mechanisms of cirrus cloud formation., Science, 340, 1320-1324, doi:10.1126/science.1234145, 2013.

de Boer, G., Morrison, H., Shupe, M. D., and Hildner, R.: Evidence of liquid dependent ice nucleation in high-latitude stratiform clouds from surface remote sensors, Geophys. Res. Lett., 38, L01803, doi:10.1029/2010GL046016, 2011.

DeMott, P. J., Sassen, K., Poellot, M. R., Baumgardner, D., Rogers, D. C., Brooks, S. D., Prenni, A. J., and Kreidenweis, S. M.: African dust aerosols as atmospheric ice nuclei, Geophys. Res. Lett., 30, 1732, doi:10.1029/2003GL017410, 2003.

DeMott, P. J., Prenni, A. J., Liu, X., Kreidenweis, S. M., Petters, M. D., Twohy, C. H., Richardson, M. S., Eidhammer, T., and Rogers, D. C.: Predicting global atmospheric ice nuclei distributions and their impacts on climate., P. Natl. Acad. Sci. USA, 107, 11217-11222, doi:10.1073/pnas.0910818107, 2010.

Domine, F., Taillandier, A. S., Simpson, W. R., and Severin, K.: Specific surface area, density and microstructure of frost flowers, Geophys. Res. Lett., 32, 1-4, doi:10.1029/2005GL023245, 2005.

Emersic, C., Connolly, P. J., Boult, S., Campana, M., and Li, Z.: Investigating the discrepancy between wet-suspension- and drydispersion-derived ice nucleation efficiency of mineral particles, Atmos. Chem. Phys., 15, 11311-11326, doi:10.5194/acp15-11311-2015, 2015.

Feick, S., Kronholm, K., and Schweizer, J.: Field observations on spatial variability of surface hoar at the basin scale, J. Geophys. Res., 112, 1-16, doi:10.1029/2006JF000587, 2007.

Field, P. R., Heymsfield, A. J., Shipway, B. J., DeMott, P. J., Pratt, K. A., Rogers, D. C., Stith, J., and Prather, K. A.: Ice in Clouds Experiment - Layer Clouds. Part II: Testing Characteristics of Heterogeneous Ice Formation in Lee Wave Clouds, J. Atmos. Sci., 69, 1066-1079, doi:10.1175/JAS-D-11-026.1, 2012.

Galek, G., Sobik, M., Blaś, M., Polkowska, Z., CichalaKamrowska, K., and Walaszek, K.: Dew and hoarfrost frequency, formation efficiency and chemistry in Wroclaw, Poland, Atmos. Res., 151, 120-129, doi:10.1016/j.atmosres.2014.05.006, 2015.

Galewsky, J. and Sobel, A.: Moist Dynamics and Orographic Precipitation in Northern and Central California during the New Year's Flood of 1997, Mon. Weather Rev., 133, 1594-1612, doi:10.1175/MWR2943.1, 2005.

Geever, M., O’Dowd, C. D., van Ekeren, S., Flanagan, R., Nilsson, E. D., de Leeuw, G., and Rannik, Ü.: Submicron sea spray fluxes, Geophys. Res. Lett., 32, 2-5, doi:10.1029/2005GL023081, 2005.

Hachikubo, A. and Akitaya, E.: Effect of wind on surface hoar growth on snow, J. Geophys. Res., 102, 4367-4373, doi:10.1029/96JD03456, 1997.

Hallett, J. and Mossop, S. C.: Production of secondary ice particles during the riming process, Nature, 249, 26-28, doi:10.1038/249026a0, 1974.

Harrington, J. Y., Meyers, M. P., Walko, R. L., and Cotton, W. R.: Parameterization of Ice Crystal Conversion Processes Due to Vapor Deposition for Mesoscale Models Using Double-Moment Basis Functions. Part I: Basic Formulation and Parcel Model 
Results, J. Atmos. Sci., 52, 4344-4366, doi:10.1175/15200469(1995)052<4344:POICCP>2.0.CO;2, 1995.

Harris-Hobbs, R. L. and Cooper, W. A.: Field Evidence Supporting Quanitative Predictions of Secondary Ice Production, J. Atmos. Sci., 44, 1071-1082, doi:10.1175/15200469(1987)044<1071:FESQPO>2.0.CO;2, 1987.

Helbig, N. and Van Herwijnen, A.: Modeling the spatial distribution of surface hoar in complex topography, Cold Reg. Sci. Technol., 82, 68-74, doi:10.1016/j.coldregions.2012.05.008, 2012.

Hogan, R. J., Field, P. R., Illingworth, A. J., Cotton, R. J., and Choularton, T. W.: Properties of embedded convection in warm-frontal mixed-phase cloud from aircraft and polarimetric radar, Q. J. Roy. Meteor. Soc., 128, 451-476, doi:10.1256/003590002321042054, 2002.

Hoose, C. and Möhler, O.: Heterogeneous ice nucleation on atmospheric aerosols: a review of results from laboratory experiments, Atmos. Chem. Phys., 12, 9817-9854, doi:10.5194/acp-12-98172012, 2012.

Horton, S., Bellaire, S., and Jamieson, B.: Modelling the formation of surface hoar layers and tracking post-burial changes for avalanche forecasting, Cold Reg. Sci. Technol., 97, 81-89, doi:10.1016/j.coldregions.2013.06.012, 2014.

Huang, Y., Blyth, A. M., Brown, P. R. A., Choularton, T. W., Connolly, P., Gadian, A. M., Jones, H., Latham, J., Cui, Z., and Carslaw, K.: The development of ice in a cumulus cloud over southwest England, New J. Phys., 10, 105021, doi:10.1088/1367-2630/10/10/105021, 2008.

Koop, T., Luo, B., Tsias, A., and Peter, T.: Water activity as the determinant for homogeneous ice nucleation in aqueous solutions, Nature, 406, 611-614, doi:10.1038/35020537, 2000.

Korolev, A. V. and Mazin, I. P.: Supersaturation of Water Vapor in Clouds, J. Atmos. Sci., 60, 2957-2974, doi:10.1175/15200469(2003)060<2957:SOWVIC>2.0.CO;2, 2003.

Kunz, M. and Kottmeier, C.: Orographic enhancement of precipitation over low mountain ranges. Part II: Simulations of heavy precipitation events over southwest Germany, J. Appl. Meteorol. Clim., 45, 1041-1055, doi:10.1175/JAM2390.1, 2006.

Lance, S., Brock, C. A., Rogers, D., and Gordon, J. A.: Water droplet calibration of the Cloud Droplet Probe (CDP) and inflight performance in liquid, ice and mixed-phase clouds during ARCPAC, Atmos. Meas. Tech., 3, 1683-1706, doi:10.5194/amt3-1683-2010, 2010.

Lawson, R., Baker, B., Schmitt, C. G., and Jensen, T. L.: An overview of microphysical properties of Arctic clouds observed in May and July 1998 during FIRE ACE, J. Geophys. Res., 106, 14989-15014, 2001.

Lawson, R. P., O’Connor, D., Zmarzly, P., Weaver, K., Baker, B., Mo, Q., and Jonsson, H.: The 2D-S (stereo) probe: Design and preliminary tests of a new airborne, high-speed, high-resolution particle imaging probe, J. Atmos. Ocean. Tech., 23, 1462-1477, doi:10.1175/JTECH1927.1, 2006.

Lawson, R. P., Woods, D., and Morrison, H.: The Microphysics of Ice and Precipitation Development in Tropical Cumulus Clouds, J. Atmos. Sci., 72, 2429-2445, doi:10.1175/JAS-D-14-0274.1, 2015.

Lehning, M., Löwe, H., Ryser, M., and Raderschall, N.: Inhomogeneous precipitation distribution and snow transport in steep terrain, Water Resour. Res., 44, 1-19, doi:10.1029/2007WR006545, 2008
Lloyd, G., Dearden, C., Choularton, T. W., Crosier, J., and Bower, K. N.: Observations of the Origin and Distribution of Ice in Cold, Warm, and Occluded Frontal Systems during the DIAMET Campaign, Mon. Weather Rev., 142, 4230-4255, doi:10.1175/MWRD-13-00396.1, 2014.

Lloyd, G., Choularton, T. W., Bower, K. N., Gallagher, M. W., Connolly, P. J., Flynn, M., Farrington, R., Crosier, J., Schlenczek, O., Fugal, J., and Henneberger, J.: The origins of ice crystals measured in mixed-phase clouds at the high-alpine site Jungfraujoch, Atmos. Chem. Phys., 15, 12953-12969, doi:10.5194/acp15-12953-2015, 2015.

Lohmann, U. and Feichter, J.: Global indirect aerosol effects: a review, Atmos. Chem. Phys., 5, 715-737, doi:10.5194/acp-5-7152005, 2005.

Lynn, B., Khain, A., Rosenfeld, D., and Woodley, W. L.: Effects of aerosols on precipitation from orographic clouds, J. Geophys. Res.-Atmos., 112, 1-13, doi:10.1029/2006JD007537, 2007.

Mason, B. J.: The rapid glaciation of slightly supercooled cumulus clouds, Q. J. Roy. Meteor. Soc., 122, 357-365, doi:10.1256/smsqj.53002, 1996.

Meyers, M. P., DeMott, P. J., and Cotton, W. R.: New Primary Ice-Nucleation Parameterizations in an Explicit Cloud Model, J. Appl. Meteorol., 31, 708-721, doi:10.1175/15200450(1992)031<0708:NPINPI>2.0.CO;2, 1992.

Möhler, O., DeMott, P. J., Vali, G., and Levin, Z.: Microbiology and atmospheric processes: the role of biological particles in cloud physics, Biogeosciences, 4, 1059-1071, doi:10.5194/bg-4-10592007, 2007.

Morrison, H., Curry, J. A., Khvorostyanov, V. I., Science, A., and Observatory, C. A.: A New Double-Moment Microphysics Parameterization for Application in Cloud and Climate Models. Part I: Description, J. Atmos. Sci., 62, 1665-1677, doi:10.1175/JAS3447.1, 2005.

Morrison, H., Thompson, G., and Tatarskii, V.: Impact of Cloud Microphysics on the Development of Trailing Stratiform Precipitation in a Simulated Squall Line: Comparison of One- and Two-Moment Schemes, Mon. Weather Rev., 137, 991-1007, doi:10.1175/2008MWR2556.1, 2009.

Mossop, S. C. and Hallett, J.: Ice crystal concentration in cumulus clouds: influence of the drop spectrum, Science, 186, 632-634, doi:10.1126/science.186.4164.632, 1974.

Muhlbauer, A. and Lohmann, U.: Sensitivity Studies of AerosolCloud Interactions in Mixed-Phase Orographic Precipitation, J. Atmos. Sci., 66, 2517-2538, doi:10.1175/2009JAS3001.1, 2009.

Murray, B. J., Broadley, S. L., Wilson, T. W., Atkinson, J. D., and Wills, R. H.: Heterogeneous freezing of water droplets containing kaolinite particles, Atmos. Chem. Phys., 11, 4191-4207, doi:10.5194/acp-11-4191-2011, 2011.

Na, B. and Webb, R. L.: A fundamental understanding of factors affecting frost nucleation, Int. J. Heat Mass Tran., 46, 3797-3808, doi:10.1016/S0017-9310(03)00194-7, 2003.

Niemand, M., Möhler, O., Vogel, B., Vogel, H., Hoose, C., Connolly, P. J., Klein, H., Bingemer, H., DeMott, P. J., Skrotzki, J., and Leisner, T.: A Particle-Surface-Area-Based Parameterization of Immersion Freezing on Desert Dust Particles, J. Atmos. Sci., 69, 3077-3092, doi:10.1175/JAS-D-11-0249.1, 2012.

Perovich, D. K. and Richter-Menge, J. A.: Surface characteristics of lead ice, J. Geophys. Res., 99, 16341-16350, doi:10.1029/94JC01194, 1994. 
Polkowska, Z., Sobik, M., Blas, M., Klimaszewska, K., Walna, B., and Namiesnik, J.: Hoarfrost and rime chemistry in Poland - An introductory analysis from meteorological perspective, J. Atmos. Chem., 62, 5-30, doi:10.1007/s10874-009-9141-6, 2009.

Pratt, K. A., DeMott, P. J., French, J. R., Wang, Z., Westphal, D. L., Heymsfield, A. J., Twohy, C. H., Prenni, A. J., and Prather, K. A.: In situ detection of biological particles in cloud ice-crystals, Nat. Geosci., 2, 398-401, doi:10.1038/ngeo521, 2009.

Prenni, A. J., Petters, M. D., Kreidenweis, S. M., Heald, C. L., Martin, S. T., Artaxo, P., Garland, R. M., Wollny, A. G., and Pöschl, U.: Relative roles of biogenic emissions and Saharan dust as ice nuclei in the Amazon basin, Nat. Geosci., 2, 402-405, doi:10.1038/ngeo517, 2009.

Rankin, A. M. and Wolff, E. W.: A year-long record of sizesegregated aerosol composition at Halley, Antarctica, J. Geophys. Res., 108, 1-12, doi:10.1029/2003JD003993, 2003.

Rankin, A. M., Wolff, E. W., and Martin, S.: Frost flowers: Implications for tropospheric chemistry and ice core interpretation, J. Geophys. Res.-Atmos., 107, 4683, doi:10.1029/2002JD002492, 2002.

Rasmussen, R. M. R., Geresdi, I., Thompson, G., Manning, K., and Karplus, E.: Freezing Drizzle Formation in Stably Stratified Layer Clouds: The Role of Radiative Cooling of Cloud Droplets, Cloud Condensation Nuclei, and Ice Initiation, J. Atmos. Sci., 59, 837-860, doi:10.1175/15200469(2002)059<0837:FDFISS > 2.0.CO;2, 2002.

Roe, G. H.: Orographic Precipitation, Annu. Rev. Earth Pl. Sc., 33, 645-671, doi:10.1146/annurev.earth.33.092203.122541, 2005.

Rogers, D. C. and Vali, G.: Ice Crystal Production by Mountain Surfaces, J. Clim. Appl. Meteorol., 26, 1152-1168, doi:10.1175/1520-0450(1987)026<1152:ICPBMS>2.0.CO;2, 1987.

Roscoe, H. K., Brooks, B., Jackson, A. V., Smith, M. H., Walker, S. J., Obbard, R. W., and Wolff, E. W.: Frost flowers in the laboratory: Growth, characteristics, aerosol, and the underlying sea ice, J. Geophys. Res., 116, D12301, doi:10.1029/2010JD015144, 2011.

Rotunno, R. and Houze, R. A.: Lessons on orographic precipitation from the Mesoscale Alpine Programme, Q. J. Roy. Meteor. Soc., 133, 811-830, doi:10.1002/qj.67, 2007.

Sassen, K., DeMott, P. J., Prospero, J. M., and Poellot, M. R.: Saharan dust storms and indirect aerosol effects on clouds: CRYSTAL-FACE results, Geophys. Res. Lett., 30, 1633, doi:10.1029/2003GL017371, 2003.

Schmitt, C. G. and Heymsfield, A. J.: Observational quantification of the separation of simple and complex atmospheric ice particles, Geophys. Res. Lett., 41, 1301-1307, doi:10.1002/2013GL058781, 2014.

Shea, C. and Jamieson, B.: Spatial distribution of surface hoar crystals in sparse forests, Nat. Hazards Earth Syst. Sci., 10, $1317-$ 1330, doi:10.5194/nhess-10-1317-2010, 2010.

Skamarock, W. C., Klemp, J. B., Dudhia, J., Gill, D. O., Barker, D. M., Duda, M. G., Huang, X.-Y., Wang, W., Powers, J. G., and Baker, D. M.: A description of the advanced research WRF version 3, Tech. Rep. June, available at: http://www2.mmm.ucar. edu/wrf/users/docs/arw_v3.pdf (last access: 20 January 2016), 2008 .
Stossel, F., Guala, M., Fierz, C., Manes, C., and Lehning, M.: Micrometeorological and morphological observations of surface hoar dynamics on a mountain snow cover, Water Resour. Res., 46, 1-11, doi:10.1029/2009WR008198, 2010.

Style, R. W. and Worster, M. G.: Frost flower formation on sea ice and lake ice, Geophys. Res. Lett., 36, 20-23, doi:10.1029/2009GL037304, 2009.

Targino, A. C., Coe, H., Cozic, J., Crosier, J., Crawford, I., Bower, K., Flynn, M., Gallagher, M., Allan, J., Verheggen, B., Weingartner, E., Baltensperger, U., and Choularton, T.: Influence of particle chemical composition on the phase of cold clouds at a high-alpine site in Switzerland, J. Geophys. Res., 114, D18206, doi:10.1029/2008JD011365, 2009.

Thompson, G., Rasmussen, R. M., and Manning, K.: Explicit Forecasts of Winter Precipitation Using an Improved Bulk Microphysics Scheme. Part I: Description and Sensitivity Analysis, Mon. Weather Rev., 132, 519-542, doi:10.1175/15200493(2004)132<0519:EFOWPU>2.0.CO;2, 2004.

Twomey, S.: Pollution and the planetary albedo, Atmos. Environ., 8, 1251-1256, doi:10.1016/0004-6981(74)90004-3, 1974.

Vali, G.: Nucleation terminology, J. Aerosol Sci., 16, 575-576, doi:10.1016/0021-8502(85)90009-6, 1985.

Vali, G., Leon, D., and Snider, J. R.: Ground-layer snow clouds, Q. J. Roy. Meteor. Soc., 138, 1507-1525, doi:10.1002/qj.1882, 2012.

Verheggen, B., Cozic, J., Weingartner, E., Bower, K., Mertes, S., Connolly, P., Gallagher, M., Flynn, M., Choularton, T., and Baltensperger, U.: Aerosol partitioning between the interstitial and the condensed phase in mixed-phase clouds, J. Geophys. Res., 112, D23202, doi:10.1029/2007JD008714, 2007.

Vionnet, V., Martin, E., Masson, V., Guyomarc'h, G., NaaimBouvet, F., Prokop, A., Durand, Y., and Lac, C.: Simulation of wind-induced snow transport and sublimation in alpine terrain using a fully coupled snowpack/atmosphere model, The Cryosphere, 8, 395-415, doi:10.5194/tc-8-395-2014, 2014.

Westbrook, C. D. and Illingworth, A. J.: Evidence that ice forms primarily in supercooled liquid clouds at temperatures $>-27^{\circ} \mathrm{C}$, Geophys. Res. Lett., 38, L14808, doi:10.1029/2011GL048021, 2011.

Westbrook, C. D. and Illingworth, A. J.: The formation of ice in a long-lived supercooled layer cloud, Q. J. Roy. Meteor. Soc., 139, 2209-2221, doi:10.1002/qj.2096, 2013.

Xiao, H., Yin, Y., Jin, L., Chen, Q., and Chen, J.: Simulation of aerosol effects on orographic clouds and precipitation using WRF model with a detailed bin microphysics scheme, Atmos. Sci. Lett., 15, 134-139, doi:10.1002/as12.480, 2014.

$\mathrm{Xu}$, L., Russell, L. M., Somerville, R. C. J., and Quinn, P. K.: Frost flower aerosol effects on Arctic wintertime longwave cloud radiative forcing, J. Geophys. Res.-Atmos., 118, 13282-13291, doi:10.1002/2013JD020554, 2013.

Zubler, E. M., Lohmann, U., Lüthi, D., Schär, C., and Muhlbauer, A.: Statistical Analysis of Aerosol Effects on Simulated MixedPhase Clouds and Precipitation in the Alps, J. Atmos. Sci., 68, 1474-1492, doi:10.1175/2011JAS3632.1, 2011. 